NBER WORKING PAPER SERIES

\title{
EVOLUTION AND REVOLUTION IN THE ARGENTINE BANKING SYSTEM UNDER CONVERTIBILITY: THE ROLES OF CRISES AND PATH DEPENDENCE
}

\author{
Lee J. Alston \\ Andrés A. Gallo \\ Working Paper 8008 \\ http://www.nber.org/papers/w8008 \\ NATIONAL BUREAU OF ECONOMIC RESEARCH \\ 1050 Massachusetts Avenue \\ Cambridge, MA 02138 \\ November 2000
}

We thank the Center for International Business Education and Research at the University of Illinois for financial support. For comments on an earlier draft we thank Michael Bordo, George Clarke, Robert Cull, Jeffrey Nugent, Eric Rasmussen, Jean-Laurent Rosenthal, Pablo Spiller, Alan Taylor, Mariano Tommasi, George von Furstenburg, Elmus Wicker and participants at seminars at Indiana University, UCLA and USC. The views expressed in this paper are those of the authors and not necessarily those of the National Bureau of Economic Research.

(C) 2000 by Lee J. Alston and Andrés Gallo. All rights reserved. Short sections of text, not to exceed two paragraphs, may be quoted without explicit permission provided that full credit, including (C) notice, is given to the source. 
Evolution and Revolution in the Argentine Banking System under

Convertibility: The Roles of Crises and Path Dependence

Lee J. Alston and Andrés Gallo

NBER Working Paper No. 8008

November 2000

JEL No. E52, G21, G28

\begin{abstract}
We provide an analytical narrative of the political and economic causes and consequences of institutional changes in the Argentine banking system. We devote most of our attention to the privatization of the provincial banks. Our story differs from the prevailing wisdom in its stress on the key roles played by convertibility and an independent Central Bank rather than the Fondo Fiduciario.

Lee J. Alston

University of Illinois at Urbana-Champaign Department of Economics 1206 South Sixth Street Urbana, IL 61801

and NBER

1-alston@uiuc.edu

Andrés Gallo

University of Illinois at Urbana-Champaign Department of Economics 1206 South Sixth Street

Urbana, IL 61801

agallo@uiuc.edu
\end{abstract}




\section{Introduction}

In this paper we analyze the roles of crisis and path dependence in determining the revolutionary and evolutionary changes in the banking system in Argentina under the convertibility plan. The Argentine banking system underwent two revolutionary changes in the 1990s: 1) in response to hyperinflations in 1989 and 1991, Argentina established a convertibility plan in April 1991 and freed the Central Bank from the influence of the executive branch in October 1992; and 2) in response to the Mexican crisis of December 1994, Argentina privatized most of the provincial banks as well as initiating a restructuring process for private banks that continues today. The initiation of convertibility and independence of the Central Bank fostered economic growth and the positive feedback from growth enabled the banking system to evolve in ways to solidify the changes put in place.

Previous discussions of the political economy of the privatization of provincial banks stress the role of the IMF and the creation of the Fondo Fiduciario, which "bought" the bad debts of the provincial banks. We do not deny the importance of the fund (especially for the livelihood of politicians) but we stress the more important role played by the independence of the Central Bank, which was linked to the Convertibility Plan. It had long been the practice of provincial politicians to use the provincial banks as a source of loans both for election purposes and public works. Many of these loans could not be repaid from the revenues generated by the public works but, before independence of the central bank, provincial politicians relied on their political influence with the central government (who in turn used their influence on the Central Bank) to monetize the debts of provincial banks. The critical institutional changes of the Convertibility Plan and the Central Bank independence, though in the short run having the unintended consequence of keeping Provincial banks afloat, in the long run were the ultimate determinant of the privatization of Provincial banks. Convertibility and Central Bank independence were not binding constraints on provincial politicians until the Mexican crisis of December 1994 because of the massive inflow of deposits resulting from the Convertibility Plan.

In Section II we discuss the economic conditions leading to the Argentine Convertibility Plan. In Section III we then use an institutional framework that incorporates both political and economic factors to interpret the time path of the evolution and revolution in the Argentine banking system. Next, (Section IV), we present evidence on individual provincial banks, indicating the importance of public loans in explaining the likelihood of subsequent privatization. Finally, in Section V we present econometric tests of causality between institutional change and 
indicators of the banking system, e.g. deposits and credit. The results are consistent with the institutional narrative presented in the preceding sections.

\section{Crisis and the Convertibility Plan}

"Offixing an exchange value relative to circulating paper money, with the objective of avoiding great oscillations which cause great unrest for commerce...not only to maintain morale and public faith, but also to prevent the demonetization of paper itself..."

Norberto de la Riestra recommendation to President

Mitre to establish Convertibility in December $1862 .^{1}$

For most of Latin America the 1980s were the "lost decade" in terms of economic performance. Economic growth was near zero, and external debt was high and mounting. In Argentina, like other countries, the policy of import substitution was abandoned and replaced with economic liberalization. Argentina finished the decade with a hyperinflation. This in turn ushered in a brief affair with monetary orthodoxy which, given the institutions in place, could not be maintained. By the beginning of 1991 a new hyperinflation ensued. Grasping at straws, the government pegged the exchange rate within a floating band but this too did not work. The government was looking for a credible commitment mechanism to ensure a stable monetary policy.

As the quote above demonstrates, Argentina had initiated an earlier convertibility plan. Convertibility is a monetary straitjacket and hence its appeal as a commitment device. The Convertibility Plan went into effect in April 1991. The convertibility law pegged the exchange rate at 1 U.S. dollar equal to 10,000 Australs ${ }^{2}$. The law stipulated that Central Bank reserves (gold and foreign currencies) had to equal $100 \%$ of the monetary base and could only be used to maintain the exchange rate (hence the term convertibility). The Central Bank essentially became a currency board whose mission was to exchange dollars for Australs at a fixed rate. ${ }^{3}$ Global financial markets viewed the law as credible because the Argentine Central Bank had the necessary reserves to cover the monetary base, i.e., the capacity to exchange all the australs in the economy for dollars. Furthermore, there were other signs of commitment: privatization of public enterprises, an openness to imports, a reduction in public employment which helped

\footnotetext{
${ }^{1}$ Quote extracted from “The Politics of Money in Mid-Nineteenth-Century Argentina." Jeremy Adelman, in "The New Insitutional Economics and Third World Develpoment."

${ }^{2}$ The peso replaced the Austral in January 1992, after which 1 US dollar $=1$ Argentinean peso.

${ }^{3}$ The Convertibility Law established: "At all times gold and foreign currency reserves of free availability in the Central Bank of the Argentine Republic will be equivalent to one hundred percent of the monetary base at least." Article 5 of the law forbade seizure: "The goods named before, that are part of the reserves cannot be under seizure and should be used for the objectives provided in the present law only."
} 
combat fiscal deficits, and most importantly the establishment of an independent central bank in October 1992. The law establishing the independence of the Central Bank (the Carta Oranica del Banco Central) needs to be viewed as a critical part of the Convertibility Plan. As a result of legislation, the Central Bank had fewer policy instruments at its disposal. Some of the changes in policy instruments were a direct result of the Convertibility Plan but others came from the legislation in October 1992. For example the he Convertibility Plan set 33\% as the percentage of reserves that could be held as federal bonds. The Convertibility Plan left reserve requirements in the hands of the Central Bank. The changes initiated by the Carta Orgánica del Banco Central include:

1. The prohibition of loans to Provincial and central governments. Though these loans were not possible under convertibilty the former legislation concerning the Central Bank had no clause with respect to lending.

2. The only goal of the Central Bank is to maintain the value of the currency. This clause replaced the former mandates of maintaining low employment, and economic growth.

3. The Central Bank now reports to Congress and not the Executive office as previously. In essence the Carta Orgánica del Banco Central and the Convertibility Plan should be viewed as complementary. Without explicit independence, there would always exist fears in the financial community that the executive branch would use the bank for political purposes. In Figure 1 we show the process of inflationary financing before the Convertibility Plan. ${ }^{4}$ In Figure 2, we show loans to the public sector as a percentage of total loans. Before convertibility the public banks (National, Provincial, and Municipal) held over 30\% of their loan portfolio in public sector loans. This dwarfs the loans to the public sector held by private banks. Outside of Buenos Aires, private banks held only about $1 \%$ of their loan portfolio as loans to the public sector. If many of these loans were based on political considerations and, subsequently in default, then we should observe considerable lending to the public banks from the central bank. We do. In 1991, loans from the central bank to the provincial banks amounted to $70 \%$ of the assets (Central Bank Boletin Estadistico (Several issues) and Ministry of Economy).

\footnotetext{
${ }^{4}$ We stress that, prior to convertibility, provincial bank lending for political purposes was not the major source of inflation. Several sources rank higher: the overall fiscal deficit of the federal government, the deficits of public firms, the deficit of the social security system, and the fiscal deficits of the provinces. But, after convertibility and the accompanying structural reforms at the federal level, the fiscal deficits of provinces and lending practices of provincial banks became more of a threat to the political sustainability of convertibility.IMF officials stressed the importance of reducing provinical deficits in its most recent negotiations over the most recent loan to Argentina (January 2000).
} 
Figure 1

Inflationary Financing Before the Convertibility Plan

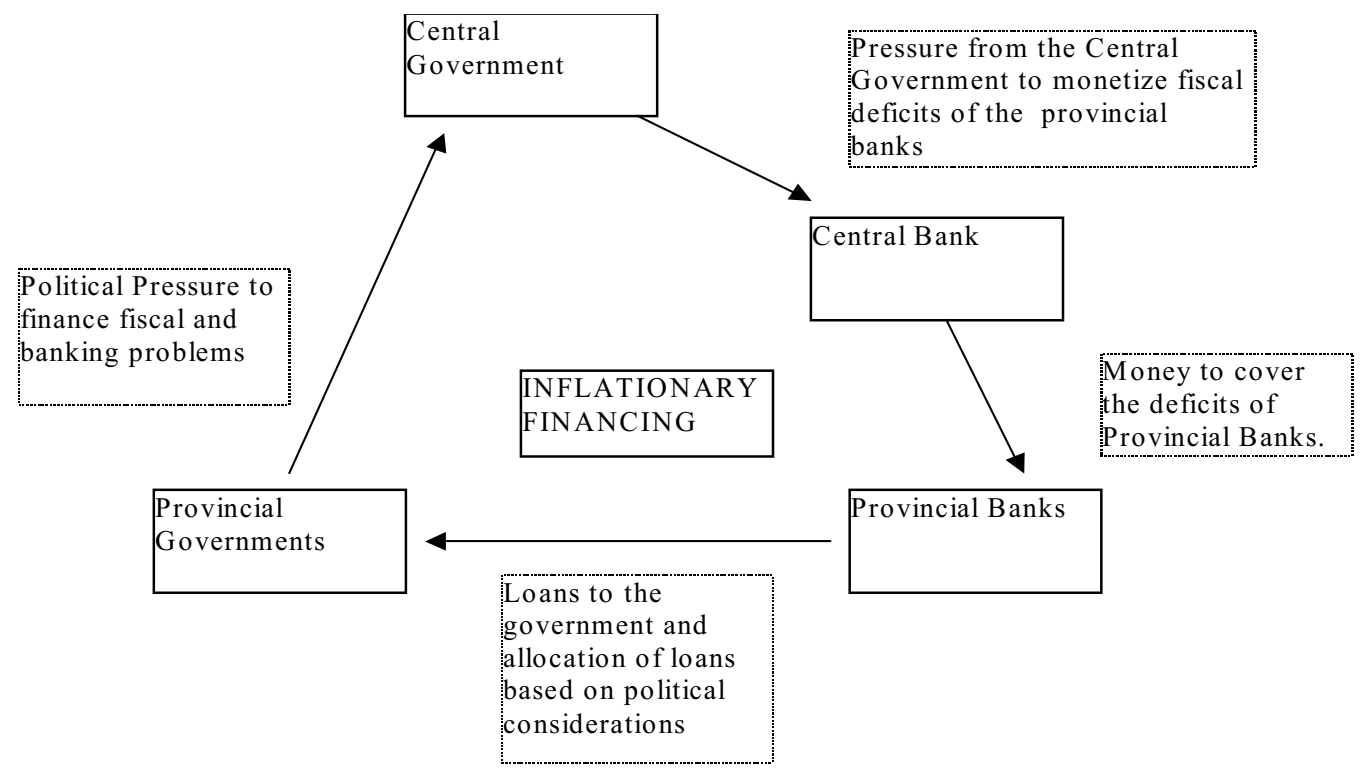

Figure 2

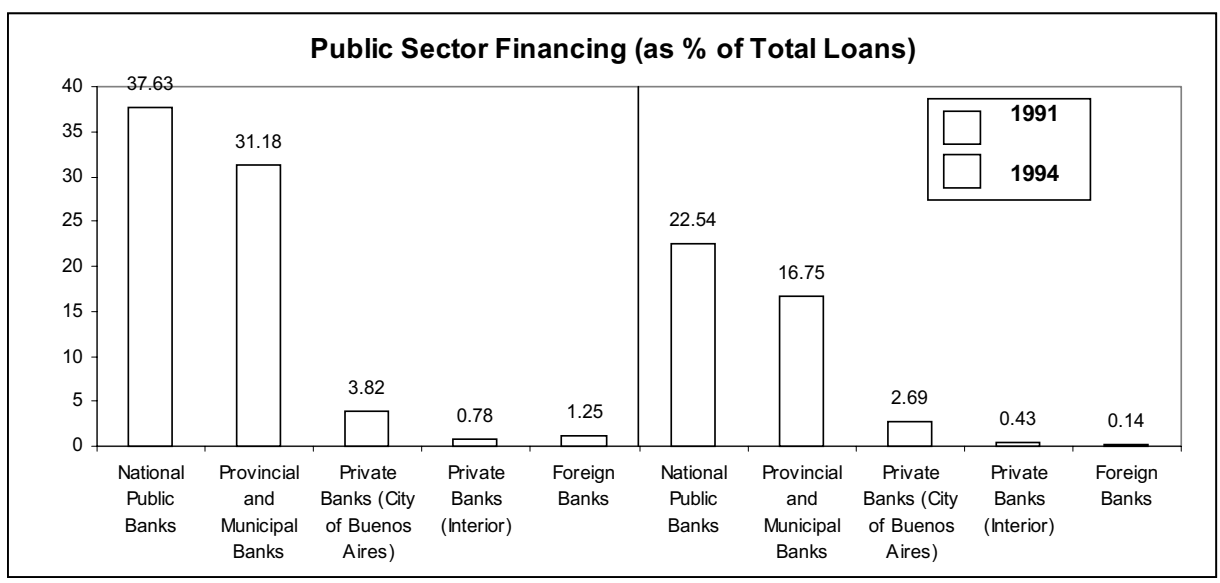

In 1991 when Argentina initiated the Convertibilty Plan many of the provincial banks were heavily indebted to the Central Bank. In Figure 3 we show the debt to deposit ratios for provincial banks with central banks. The high debts are consistent with the our framework indicating that public banks financed "political" loans and had to turn to the Central Bank to remain afloat. 
Figure 3

\section{Debt/Deposit Ratios of Provincial Banks with the Central Bank (1991)}

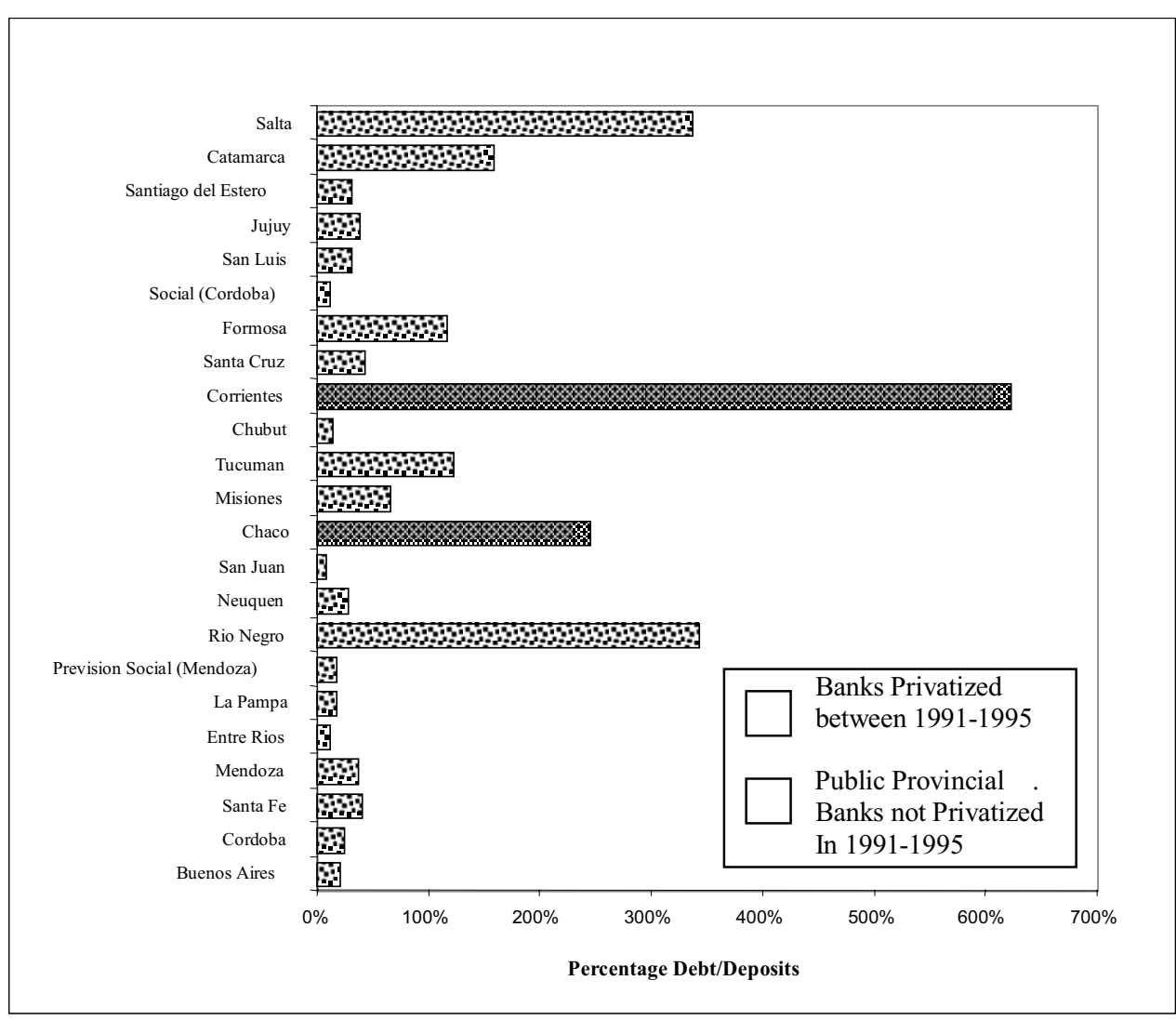

Source: Banco Central de la República Argentina and CTA(1996)

This process had to be stopped if the Convertibility Plan was to succeed. As noted above the Carta Orgánica del Banco Central dictated independence from the executive branch and prohibited the Central Bank from giving loans to the government. Furthermore, the Central Bank could only buy government bonds at market prices. The law also established the Superintendencia de Bancos, whose function it is to regulate and audit the activity of banks. In Figure 4 we show how the Convertibility Plan and new charter of the Central Bank prevented the Central Bank from monetizing the debts of the provincial banks. 
Figure 4

\section{Relationship Among Provincial Banks, the Central Government and the Central Bank After the Convertibility Plan}

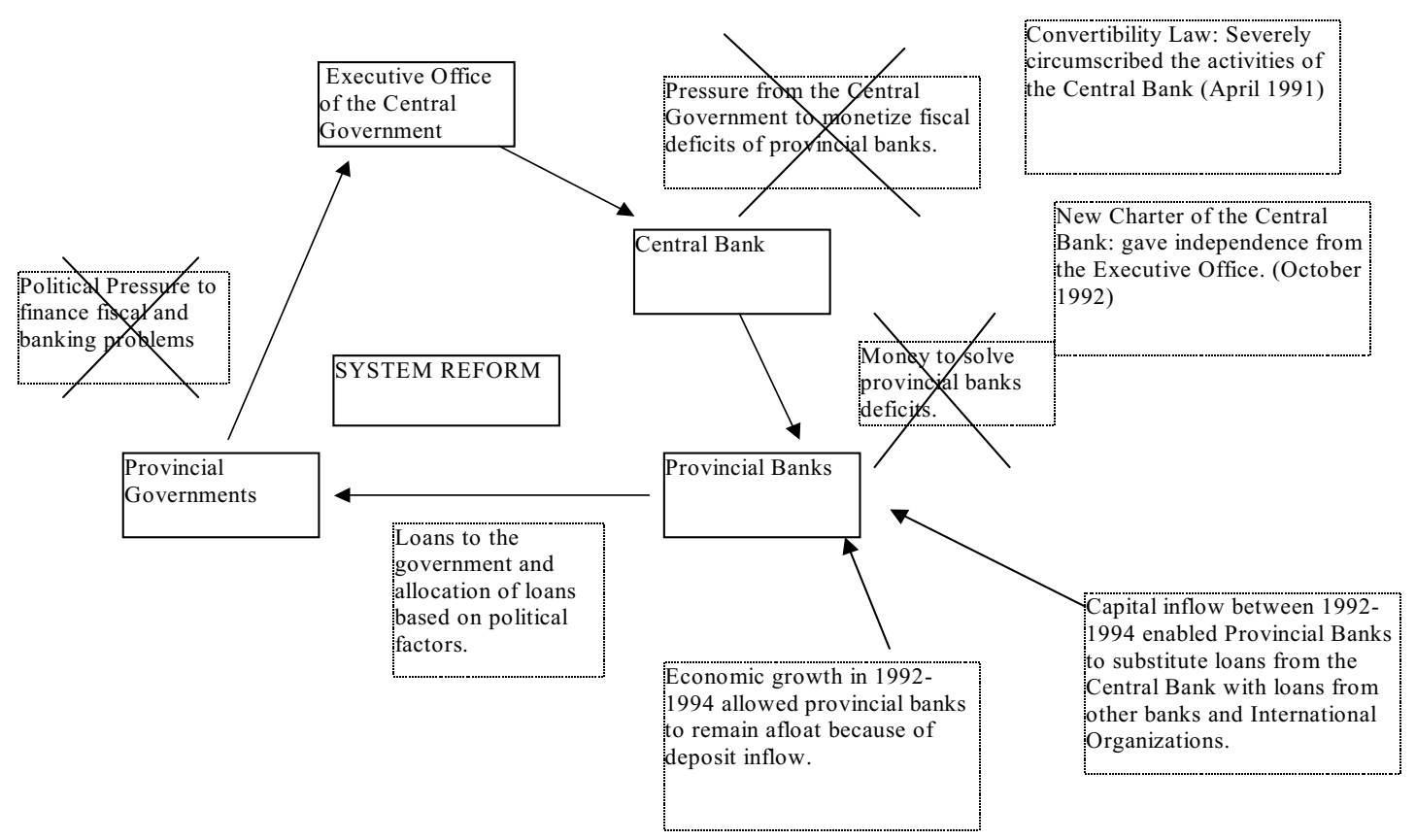

After convertibility the Central Bank no longer extended much credit to the provincial banks. Loans from the Central Bank as a percentage of assets fell from $70 \%$ before convertibility to $5 \%$ by 1994 . Although provincial banks could no longer expect help from the Central Bank, the success of the Convertibility Plan injected considerable liquidity into the banking system. The Convertibility Plan generated a huge inflow of foreign capital (direct investment and short-term financial capital), stimulating economic growth via an increase in the money supply. The mechanism worked as follows: the increased capital into the Argentine system produced an increased number of dollars in the system. The Central Bank buys these dollars (or they go directly to banks as dollar deposits - Argentina has a bimonetary financial system) and, in this way, creates money. The increase in money supply generates a decline in interest rates and as a result increased investment, thereby increasing economic growth. The repetition of this process generates a virtuous cycle that can be maintained as long as there is capital inflow. When the capital inflow stops and reverts to a capital outflow this process operates in reverse: the Central Bank is forced to sell dollars and contract the money supply. Consequently interest rates increase and investment falls prompting a decline in economic activity. If, as is the case under the Convertibility Plan, there are no restrictions to capital flows this process tends to maximize the 
growth rate of the economy during capital inflows but it correspondingly maximizes the decline in economic growth during capital outflows.

The prosperity brought about by the Convertibility Plan significantly reduced the debt burden of most of the provincial banks and in particular the debts that provincial banks had with the Central Bank. In Table 1, we show the debt/deposit ratios of provincial banks immediately following the initiation of the Convertibility Plan in 1991 and its effects three years later. Overall the debt/deposit ratio of the provincial banks with respect to the Central Bank fell from $49 \%$ to $4 \%$, though the debt/deposit ratio with other banks and international organizations took up some of the slack, increasing to nearly $20 \%$. The flow of foreign capital into Argentina was a sign of the outside world's faith in new financial system.

\section{Table 1}

Debt/Deposits of Provincial Banks

\begin{tabular}{|c|c|c|c|}
\hline & $\begin{array}{c}1991 \\
\text { Central Bank }\end{array}$ & & $\begin{array}{c}1994 \\
\text { Debt/Deposits }\end{array}$ \\
\hline Provincial Banks & Debt/Deposits & $\begin{array}{l}\text { Central } \\
\text { Bank }\end{array}$ & $\begin{array}{c}\text { Other Banks and } \\
\text { International Organizations }\end{array}$ \\
\hline Provincia of Buenos Aires & $20 \%$ & $3.0 \%$ & $14.0 \%$ \\
\hline Provincia de Cordoba & $24 \%$ & $7.0 \%$ & $48.0 \%$ \\
\hline Provincial de Santa Fe & $39 \%$ & $3.0 \%$ & $4.0 \%$ \\
\hline De Mendoza & $37 \%$ & $8.0 \%$ & $24.0 \%$ \\
\hline De Entre Rios & $11 \%$ & $6.0 \%$ & $54.0 \%$ \\
\hline De La Pampa & $17 \%$ & $0.0 \%$ & $4.0 \%$ \\
\hline De Prevision Social de Mendoza & $17 \%$ & & - \\
\hline De la Pcia. de Rio Negro & $343 \%$ & $0.0 \%$ & $85.0 \%$ \\
\hline De la Pcia. de Neuquen & $28 \%$ & $1.0 \%$ & $17.0 \%$ \\
\hline De San Juan S.A. & $8 \%$ & $7.0 \%$ & $20.0 \%$ \\
\hline Del Chaco & $245 \%$ & & - \\
\hline De la Pcia. de Misiones & $66 \%$ & $19.0 \%$ & $62.0 \%$ \\
\hline De la Pcia. de Tucuman & $122 \%$ & $1.0 \%$ & $24.0 \%$ \\
\hline De la Pcia. de Chubut & $14 \%$ & $0.0 \%$ & $4.0 \%$ \\
\hline De la Pcia. de Corrientes & $622 \%-$ & & - \\
\hline De la Pcia. de Santa Cruz & $43 \%$ & $0.0 \%$ & $1.0 \%$ \\
\hline De la Pcia. de Formosa & $116 \%$ & $0.0 \%$ & $46.0 \%$ \\
\hline Social de Cordoba & $11 \%$ & & - \\
\hline De la Pcia. de San Luis & $31 \%$ & $1.0 \%$ & $0.0 \%$ \\
\hline De la Pcia. de Jujuy & $38 \%$ & $3.0 \%$ & $8.0 \%$ \\
\hline De la Pcia. de Santiago del Estero & $31 \%$ & $0.0 \%$ & $18.0 \%$ \\
\hline De Catamarca & $159 \%$ & $77.0 \%$ & $32.0 \%$ \\
\hline Provincial de Salta & $337 \%$ & $8.0 \%$ & $53.0 \%$ \\
\hline De Tierra del Fuego & - & $0.0 \%$ & $3.0 \%$ \\
\hline Total & $49 \%$ & $4.1 \%$ & $19.7 \%$ \\
\hline
\end{tabular}


But the success of convertibility and the inflow of deposits allowed the provincial banks to continue their practice of making loans to the public sector, though at a diminished rate. By 1994, the public sector loans as a percentage of total loans had fallen from $31 \%$ in 1991 to $17 \%$ in 1994 . Rather than being forced to privatize, convertibility plan enabled the provincial banks to maintain the status quo. Undoubtedly, this was an unintended consequence of convertibility. In 1994 Provincial banks still had $30 \%$ of their loans as nonperforming.

The banking system is particularly important under the Convertibility Plan because banks are the conduits for capital flows. Deposits rise and fall in accordance with the flows. As a result of the variability of deposits, banks can experience serious liquidity problems during periods of capital outflows. The situation is exacerbated because the convertibility of the exchange rate means the relatively "inconvertibility" of deposits: if the reserves of the Central Bank are maintained in order to maintain the exchange rate, there is no role of lender of last resort for the Central Bank. Because of this inherent problem, it was recognized that banks must have their houses in order. ${ }^{5}$ In Argentina it was recognized that bank reform was needed for both private and public banks. In particular, there were calls for the privatization of provincial banks that had made a practice of making large loans to provincial governments backed only with political capital. Despite recognition of the problem, little privatization initially occurred in the banking system because the initial capital inflows from the Convertibility Plan enabled the provincial banks to stay afloat despite their loan portfolio. But the situation was not sustainable and awaited the Tequila Crisis. With this preview we now turn to an analysis of the evolution and revolution in the banking system.

\section{The Banking System: Reform from the Center and Resistance on the Periphery}

During the early years of the Convertibility Plan, there was considerable evolution in the banking system, especially with regard to the Central Bank. Because there were strict limits to the Central Bank's ability to behave as a lender of last resort during a financial crisis, they imposed high reserve and capital requirements along with other regulations. ${ }^{6}$ With the Convertibility Plan, the central government encouraged privatization of public enterprises and, in particular public banks. As part of their commitment, the central government rebated tax revenue to the provinces

\footnotetext{
${ }^{5}$ This is not a problem specific to convertibility plans but the mismatch in term structures between deposits and loans is exacerbated by the lack of policy instruments available to a central bank under a convertibility arrangement. Bank regulation has received increased attention by policy makers in the wake of bank failures following the financial crises of the 1990s. In order to minimize future bank failures the I.M.F., along with the Basle Committee, has established guidelines for banking regulation. See "Report on the Working Group on Strengthening Financial Systems.” I.M.F. October 1998.

${ }^{6}$ The regulatory framework in Argentina is tighter than the recommendations of the Basle Committee.
} 
with the understanding that this would smooth the transition from public to private enterprises. But, privatization was resisted because of the benefits received by provincial politicians. By January 1995 only 3 provincial banks had been privatized, and one of the banks privatized was from Menem's province of La Rioja. ${ }^{7}$ In Table 2, we list the provincial banks that have been privatized. Note the generally long lag between the law or decree initiating privatization and the call to offer the bank for sale, and the lag between the call for sale and ultimate privatization. All but the first two bank privatizations received money from the fiduciary fund.

Table 2

\section{Provincial Bank Privatizations}

\begin{tabular}{|l|l|l|l|l|}
\hline Bank & $\begin{array}{l}\text { Privatization } \\
\text { Law or Decree }\end{array}$ & $\begin{array}{l}\text { Call to } \\
\text { offer }\end{array}$ & Privatization & $\begin{array}{l}\text { Money Received from } \\
\text { the Fiduciary Fund } \\
\text { (USS million) }\end{array}$ \\
\hline Corrientes & $11 / 91$ & - & $5 / 93$ & - \\
\hline La Rioja & - & - & $7 / 94$ & - \\
\hline Chaco & $5 / 93$ & $7 / 94$ & $11 / 94$ & 78 \\
\hline Entre Rios & $8 / 93$ & $8 / 94$ & $1 / 95$ & 78 \\
\hline Formosa & $2 / 95$ & $3 / 95$ & $12 / 95$ & 80 \\
\hline Misiones & $11 / 94$ & $11 / 94$ & $1 / 96$ & 78 \\
\hline Rio Negro & $3 / 95$ & $8 / 95$ & $3 / 96$ & 80 \\
\hline Salta & $7 / 94$ & $8 / 95$ & $3 / 96$ & 50 \\
\hline Tucuman & $3 / 95$ & $7 / 95$ & $7 / 96$ & 80 \\
\hline San luis & $12 / 89$ & $4 / 96$ & $8 / 96$ & 50 \\
\hline Santiago del Estero & $1 / 95$ & $3 / 96$ & $9 / 96$ & 50 \\
\hline San Juan & $7 / 95$ & $11 / 95$ & $11 / 96$ & 80 \\
\hline $\begin{array}{l}\text { Prevision Social de } \\
\text { Mendoza }\end{array}$ & $3 / 95$ & $11 / 95$ & $11 / 96$ & 100 \\
\hline Mendoza & $3 / 95$ & $11 / 95$ & $11 / 96$ & 160 \\
\hline Jujuy & $6 / 95$ & $8 / 97$ & $1 / 98$ & 50 \\
\hline Santa Fe & $7 / 96$ & $9 / 97$ & $6 / 98$ & 160 \\
\hline Santa Cruz & $10 / 95$ & $3 / 98$ & $10 / 98$ & 80 \\
\hline $\begin{array}{l}\text { Municipal de } \\
\text { Tucuman }\end{array}$ & $12 / 93$ & $2 / 97$ & $7 / 98$ & 25 \\
\hline Catamarca & - & - & & 50 \\
\hline Sorival| & & & 5 \\
\hline
\end{tabular}

Source:Privatizacion de Bancos en Argentina: ¿El camino hacia una banca mas eficiente? Burdisso, D’Amato and Molinari, BCRA. October 1998.

In Figure 5 we show the amount of lending to governments by the type of banks in Argentina. All public banks lent considerably more to governments than private banks even following the Convertibility Plan. Furthermore, many of these loans were non-performing. In Figure 6 we show the percentage of loans that were in default across the types of banks in

\footnotetext{
${ }^{7}$ The Bank of La Rioja went "bankrupt" in 1991 and was forced to close by the Central Bank. It was reorganized by the legislature of La Rioja as the Nuevo Banco de La Rioja and privatized in 1994. The
} 
Argentina. At the time of the Tequila crisis in December 94, public banks had about $30 \%$ of loans in default compared to under $10 \%$ for private banks. In the next two years the situation worsened, except for foreign banks, in the provincial banks compared to loan defaults in the rest of the banking system.

Figure 5

\section{Loans to the Government/Total Portfolio}

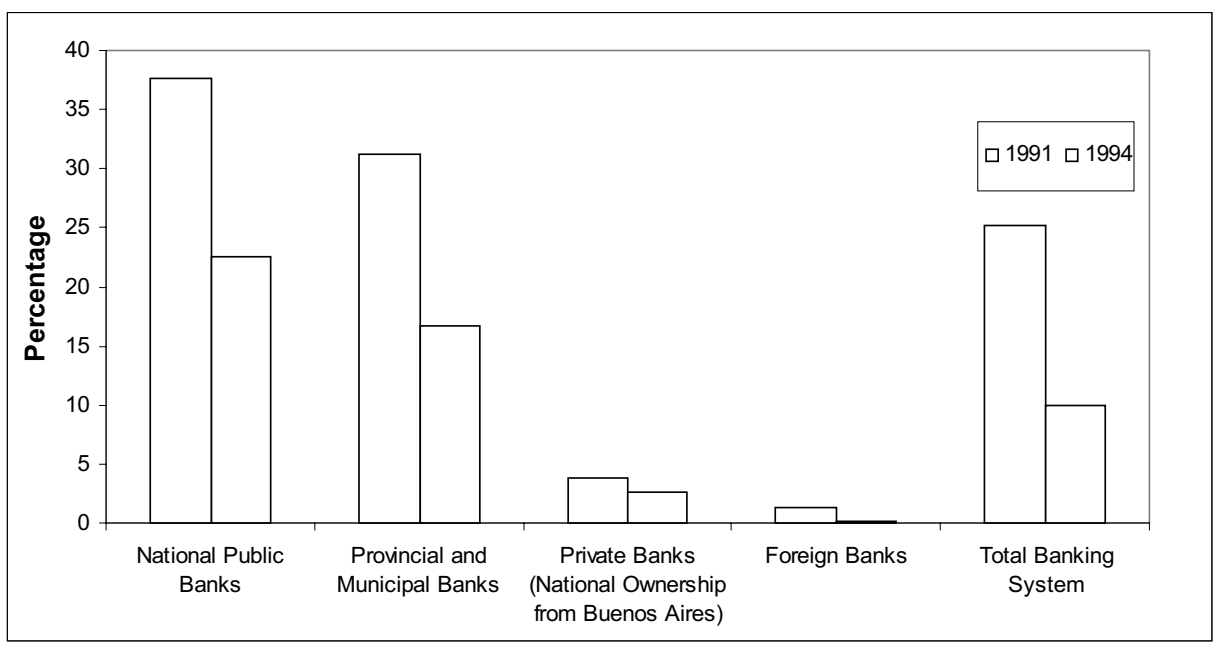

Source: Ministry of Economy of the Argentine Republic. Informe Economico. Several Issues.

Figure 6

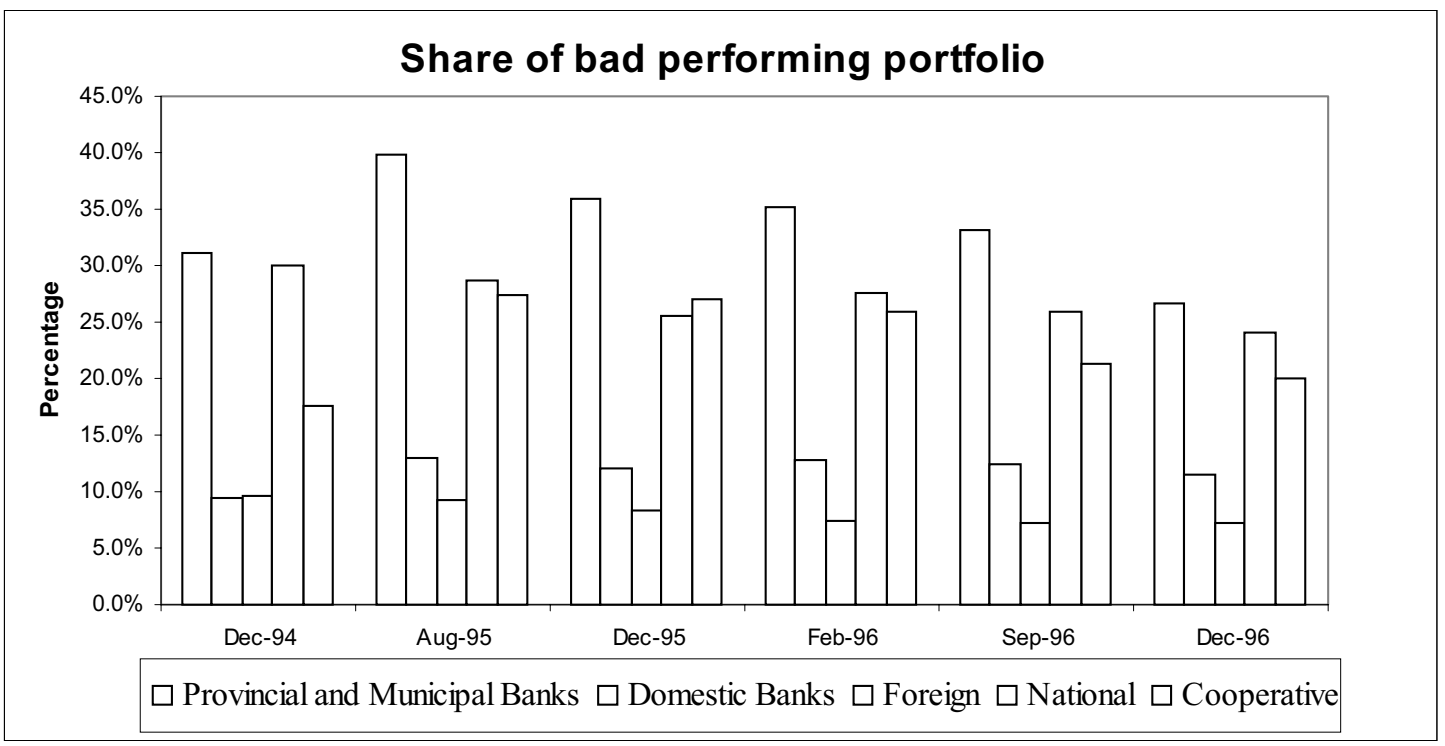

Source: Ministry of Economy of the Argentine Republic. Informe Economico. Several Issues. andres is this the right source?

bank of Corrientes went bankrupt in 1991. 
Clearly, the provincial banks were in much worse financial shape than the private banks. Yet, they were not forced into bankruptcy because the inflows of deposits into the system remained large. (See Table 3.) The increase for the system was an astonishing 170\% between 1991 and 1994. But, the huge inflows of capital and deposits brought about by the Convertibility Plan were to reverse into outflows with the Mexican Crisis of December 1994.

Table 3

\section{Deposit Inflows to Provincial Banks}

\begin{tabular}{|c|c|c|c|}
\hline \multicolumn{4}{|c|}{ Deposits } \\
\hline & $\mathbf{1 9 9 1}$ & $\mathbf{1 9 9 4}$ & Growth \\
\hline Bs. Aires & 1576 & 4298 & $172.7 \%$ \\
\hline Santa Fe & 292 & 671 & $129.8 \%$ \\
\hline Cordoba & 456 & 1038 & $127.6 \%$ \\
\hline Entre Rios & 153 & 211 & $37.9 \%$ \\
\hline Mendoza & 227 & 666 & $193.4 \%$ \\
\hline San Juan & 78 & 225 & $188.5 \%$ \\
\hline San luis & 29 & 99 & $241.4 \%$ \\
\hline La Pampa & 111 & 428 & $285.6 \%$ \\
\hline Catamarca & 23 & 53 & $130.4 \%$ \\
\hline Jujuy & 26 & 103 & $296.2 \%$ \\
\hline Salta & 13 & 53 & $307.7 \%$ \\
\hline Sgo. Del Estero & 23 & 62 & $169.6 \%$ \\
\hline Tucuman & 61 & 142 & $132.8 \%$ \\
\hline Chubut & 51 & 227 & $345.1 \%$ \\
\hline Neuquen & 92 & 293 & $218.5 \%$ \\
\hline Rio Negro & 98 & 160 & $63.3 \%$ \\
\hline Santa Cruz & 40 & 243 & $507.5 \%$ \\
\hline T. del Fuego & 39 & 144 & $269.2 \%$ \\
\hline Misiones & 68 & 159 & $133.8 \%$ \\
\hline Formosa & 36 & 124 & $244.4 \%$ \\
\hline Total & 3492 & 9399 & $169.2 \%$ \\
\hline System & 16624.44 & 44940 & $170.3 \%$ \\
\hline Source: CTA(1996) and Central Bank of the Argentine Republic \\
\hline
\end{tabular}

The devaluation of the Mexican peso in December 1994 ushered in what is known as the Tequila Crisis. The Tequila Crisis triggered capital flight from most Latin American countries despite the soundness of most of the economies. ${ }^{8}$ The trigger for the crisis in Argentina was

\footnotetext{
${ }^{8}$ There is still not a consensus on the reasons for the spread of the crisis to Argentina. A few days before the devaluation in Mexico the probability of a crisis in Argentina was considered insignificant by most economists. After the fact, some economists attribute the contagion to "herd" behavior.(See Calvo 1996, 1997, 1998 and 1999) Other explanations are more simplistic: because Argentina devalued following the last Mexican crisis, they would do so again. Finally, there are models that rely on assumptions of limited rationality with the result that multiple equilibria are possible or "anything could happen."(Calvo(1996), (1999), Calvo and Mendoza(1998), Obstfeld(1986).
} 
insolvency of the Extrader bank ${ }^{9}$, which had a substantial part of its portfolio invested in Mexican government bonds. The sudden devaluation of the Mexican peso sparked a liquidity crisis for the Extrader bank and a rush by depositors to get their money out. Though the rest of the system was for the most part sound, the run on Extrader spread across the domestic banking system. Deposits fell across the banks in the domestic sector in the early months of 1995. Between December 1994 and June 1995 deposits fell over 10\% in National Public banks and Argentine owned private banks while deposits fell over 5\% in Provincial and Municipal banks. During the same period deposits in foreign-owned banks increased 5\% (Central Bank and Ministry of Economy) Depositors were shifting away from the domestic banks with perceived bad loan portfolios. ${ }^{10}$ The Central Bank and the central government were forced to act in the face of what was now a crisis. The banking system was near collapse and policy options were limited. On the one hand, the government could have devalued and confirmed the expectations that had brought about the crisis. But this had huge political as well as economic costs. On the political side, the reputation of President Menem was tied to the Convertibility Plan and there was a Presidential election in May. On the economic side, hyperinflation would most likely have resulted because many contracts were denominated in dollars and transactors would adjust their prices accordingly. ${ }^{11}$ For example, utility and telephone companies priced in dollars. Furthermore, during the credit boom of the past few years many loans were transacted in dollar terms. A devaluation would squeeze all the borrowers who were paid with pesos. The alternative to devaluation was to stay the course of the Convertibility Plan.

To stay the course, meant making a credible commitment to privatization of the provincial banks along with other regulatory changes. Both the opposition party and the politicians from the provinces (most of whom were Peronists like Menem) gave their support to bank reform. The support by the opposition is striking because the political history in Argentina is one where the opposition revels in the failure of the incumbent. In this case there was a clear consensus to improve the Convertibility Plan through bank reform.

The Argentine Central Bank moved swiftly to stop the fear of devaluation and limit the runs on banks. In January 1995 it denominated in dollars all deposits that commercial banks held with the Central Bank. Between January and April 1995 Argentina put in place the following: 1) a $\$ 1$ billion safety net to help private banks with liquidity problems (January); 2) a deposit

\footnotetext{
${ }^{9}$ The Extrader bank was ordered to close on February 1995 by a court order.

${ }^{10}$ The movement towards foreign banks continued after the crisis. Today, $49 \%$ of bank assets are in foreign-owned banks (The Economist, November $4^{\text {th }}-10^{\text {th }} 2000$, p. 118).

${ }^{11}$ The practice of denominating in dollars began in the earlier hyperinflation periods of 1989 and 1991.
} 
insurance system (February); 3) lower reserve requirements - $43 \%$ to $30 \%$ (February) ${ }^{12}$; 4) a fund for restructuring private banks bankrolled by the World Bank, the IDB, and the U.S. (April 1995); 5) credit lines for solvent banks facing liquidity problems (April); ${ }^{13}$ and 6) the Central Bank obtained more latitude as lender of last resort (April). In addition to these changes, the most important initiative was the creation in February of a fund for the privatization of provincial banks and recaptitalization of private banks whose net worth had plummeted (Fondo Fiduciario para el Desarrollo Provincial). The IMF and the IDB put up the majority of money for the fund but Argentina contributed with a bond issue (Bono Patriotico). In March the Argentine government reached an agreement with the IMF that provided for 7 billion dollars of credit, provided the IMF monitored the financial system. The institutional changes stopped the financial crisis but not without costs on the real sector: GDP decreased 3.5\% in 1995 and the unemployment rate rose to $18 \%$.

With the help of the Fondo Fiduciario para el Desarrollo Provincial the privatization of the provincial banks was set in motion. Cull and Clarke (1997) argue that the creation of the Fondo Fiduciario para el Desarrollo Provincial by the IMF and IDB was the linchpin in the privatization process and the savior of the Convertibility Plan. We do not disagree that the Fondo Fiduciario was instrumental in smoothing privatization and, undoubtedly the injection of $\$ 1$ billion calmed the financial markets. But, the Convertibility Plan coupled with the Carta Orgánica del Banco Central in 1992 were the critical institutional changes, which, as we showed in Figure 4, severed the monetization of the debts of the provincial banks. Once the Central Bank no longer could be relied upon to cover the bad loans of the provincial banks they were only kept alive by the injection of deposits into the system. As long as there were deposits rolling into the provincial banks, they were able to satisfy the requests for public loans by the provincial politicians. This is why the provincial politicians resisted privatization. But, as soon as there was a deposit outflow, many of the provincial banks would be bankrupt and they would die; the Fondo Fiduciario made the deaths relatively painless on the creditors, and perhaps it saved the political lives of many of the provincial politicians. Provincial politicians with bankrupt banks no longer had an incentive to resist privatization because the banks could no longer lend them money. Indeed, the provincial politicians open-heartedly supported the creation of the Fondo

\footnotetext{
12 The reduction in reserve requirements injected $\$ 2.7$ billion into the system.

${ }^{13}$ For more detail on the changes see the appendix.
} 
Fiduciario. In Figure 7, we show the relationship following the Tequila Crisis among the provincial banks, the provincial politicians, the central government and the Central Bank. 
Figure 7

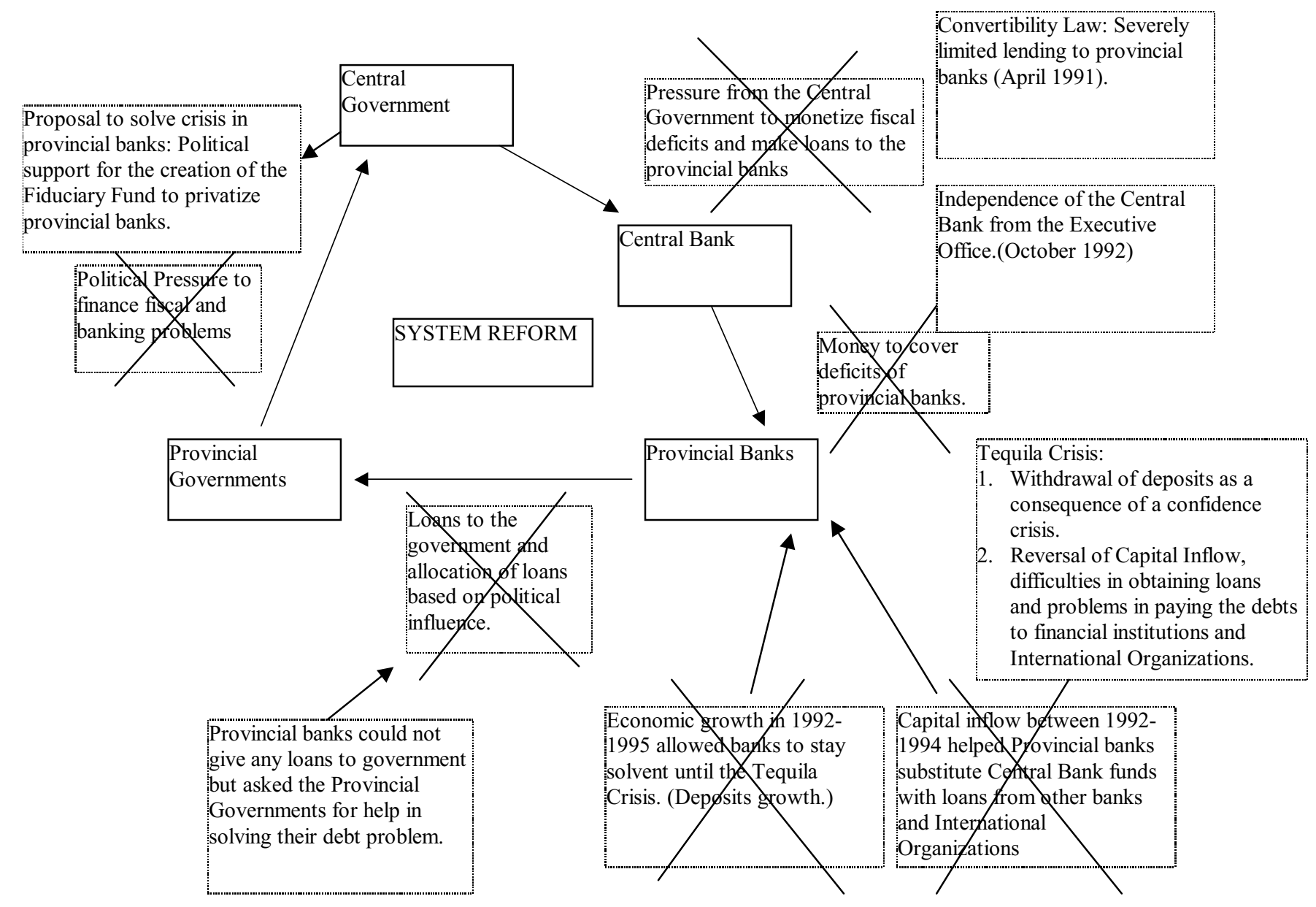


Consistent with our view is the evidence on the timing of privatization. Not all banks availed themselves of the opportunity to privatize; in Figure 8 we show that those banks most burdened with nonperforming loans privatized earlier.

Figure 8

Percentage of Loan Portfolio in Default

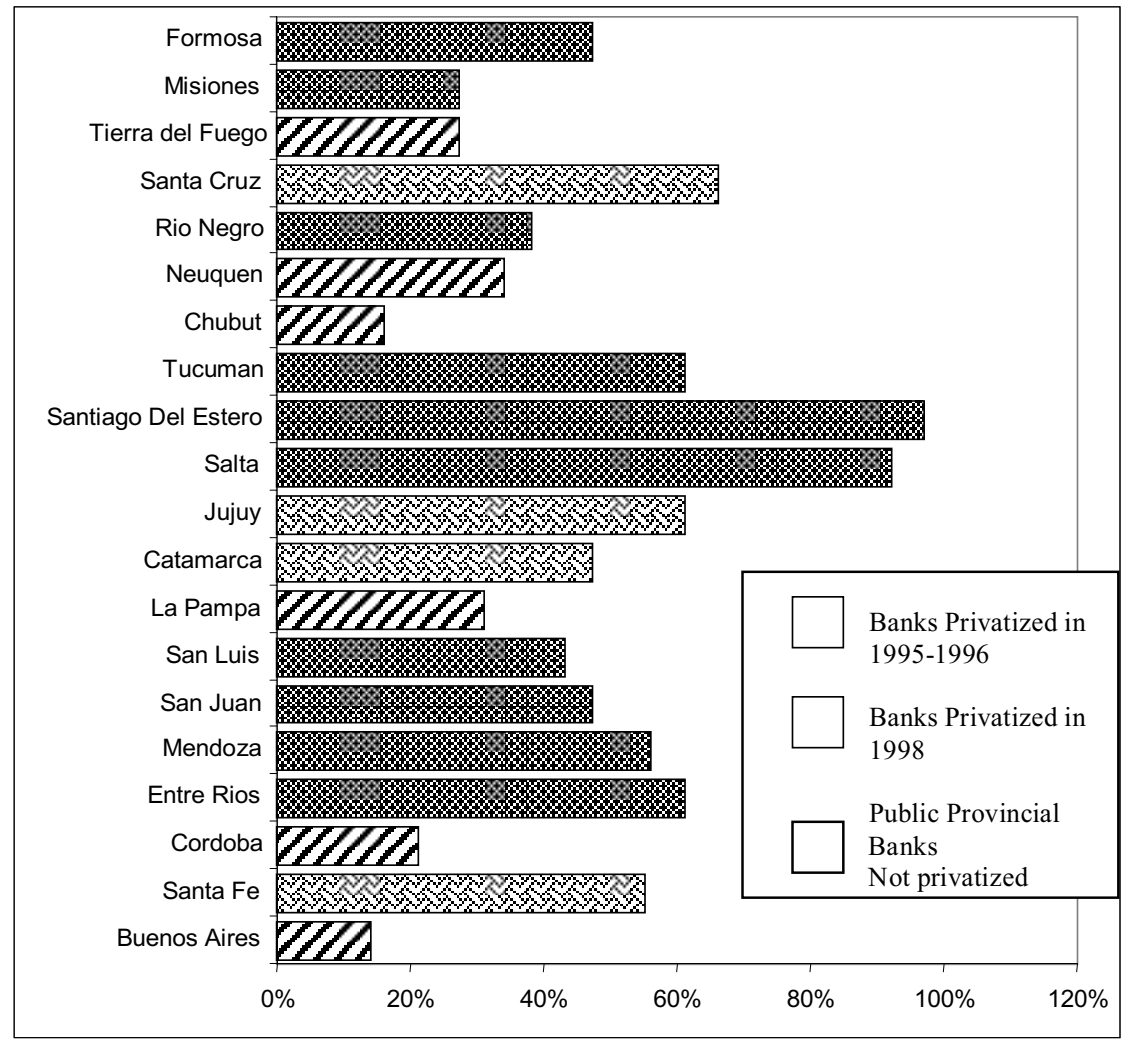

Source: Ministry of Economy of the Argentine Republic. Informe Economico, Several Issues. 
The relationship between privatization and indebtedness to other banks and multilateral institutions tells the same story (See Figure 9).

\section{Figure 9}

Indebtedness of the Provincial Banks with Other Banks and the World Bank

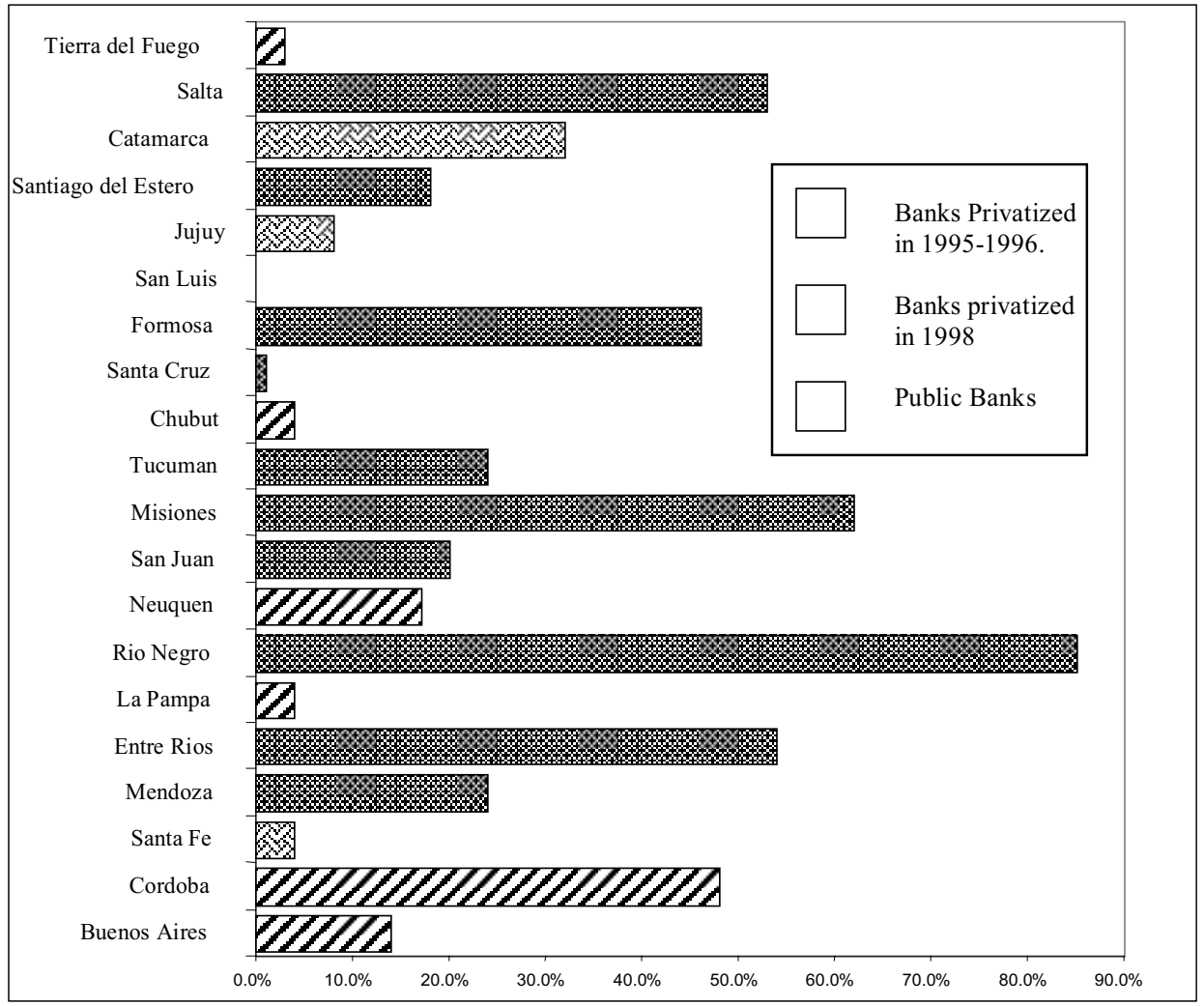

Source: CTA(1996)

Coincident with encouraging privatization, additional evolutionary regulatory steps were taken to solidify the financial system. (See the appendix for a list of the regulatory changes.) Depositors also shifted assets to larger domestic and foreign banks and, as a consequence a merger wave spread through the banking system: between January 1995 and December 1998 the number of banks fell from 206 to 130. (See Figure 10). A majority of the consolidation took place in 1995, following the Tequila crisis. With the stronger financial system that emerged in the wake of the Tequila Crisis, the Argentine banking system weathered the Asian and Russian financial crises in good shape. 
Figure 10

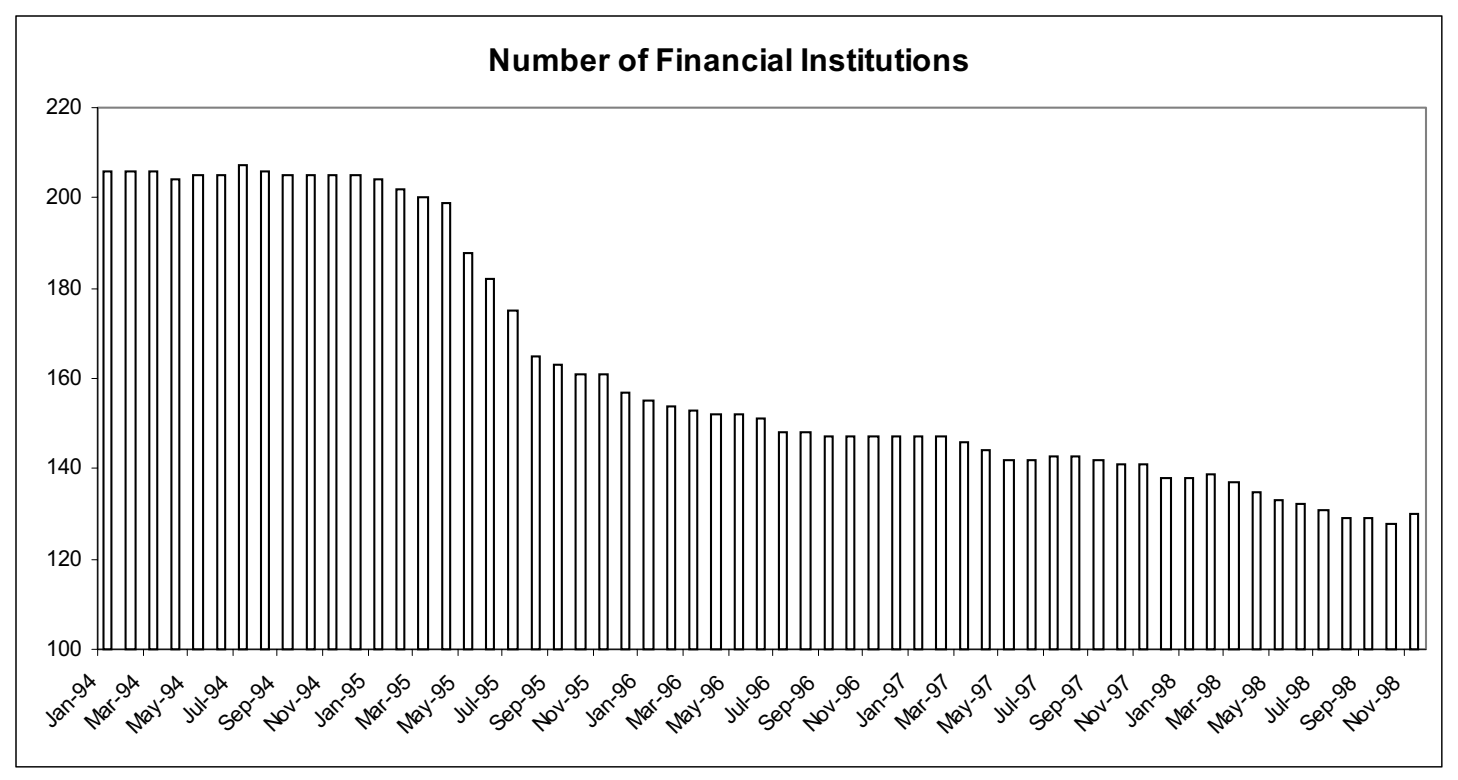

Source: Central Bank of the Argentine Republic.

\section{The Causes and Consequences of Institutional Reform in Banking}

In the preceding narrative we argued that major institutional reforms result from crises, and that, once in place, institutional deepening occurs through an evolutionary process. In the case of Argentina two financial crises rocked the banking system in the past decade: the hyperinflationary episodes of 1989 and 1991; and the Tequila crisis in December 1994. In the wake of the hyperinflation of 1989 Argentina tried vainly to patch up the system but this feeble effort was doomed and sparked the bigger hyperinflation of 1991. This episode ushered in Menem and the convertibility plan. The convertibility plan initially worked well as indicated by the growth in deposits and the overall economy. The positive growth feedback encouraged institutional deepening but it also prevented the privatization of provincial banks. But, privatization of provincial banks was inevitable because their lifeline to the Central Bank had been severed. Once the Tequila crisis hit, the provincial banks could not remain afloat. The creation of the Fondo Fiduciario by the IMF/IDB smoothed the transition but it is our contention that the end result would have been the same. The biggest impact of the Fondo Fiduciario was on the equity holders and provincial politicians. Following the reforms prompted by the Tequila crisis, there was more institutional deepening which put the banking sector on firm ground such that it was scarcely impacted by the Asian and Russian crises. 
In this section we provide quantitative evidence consistent with our narrative of revolution and evolution in the banking sector. To begin, we created an index of institutional change in the Argentina banking system from October 1992 to October 1998. Our starting date was determined by the capstone of the convertibility plan: the independence of the Central Bank. The closing date was determined by data availability. In Argentina, three players can initiate banking regulation: the legislature, the executive office, and the Central Bank. Through laws and decrees, the legislature and executive office have the authority to initiate major changes in the regulatory structure while the Central Bank can deepen the institutional changes put in place by laws or decrees. For example the legislature passed a law giving independence to the Central Bank in October 1992. The executive office, through decree, authorized the creation of the Fondo Fiduciario. The Central Bank has the authority to change the capital requirements of commercial banks.

We created our index in the following manner: minor changes in regulation from the Central Bank received either 0.5 or 1, and major changes in regulation by law or decree received a 3. Our judgment of importance followed guidelines from the Basle Committee. In Figure 11 we present a graph of the index over time. ${ }^{14}$

Figure 11

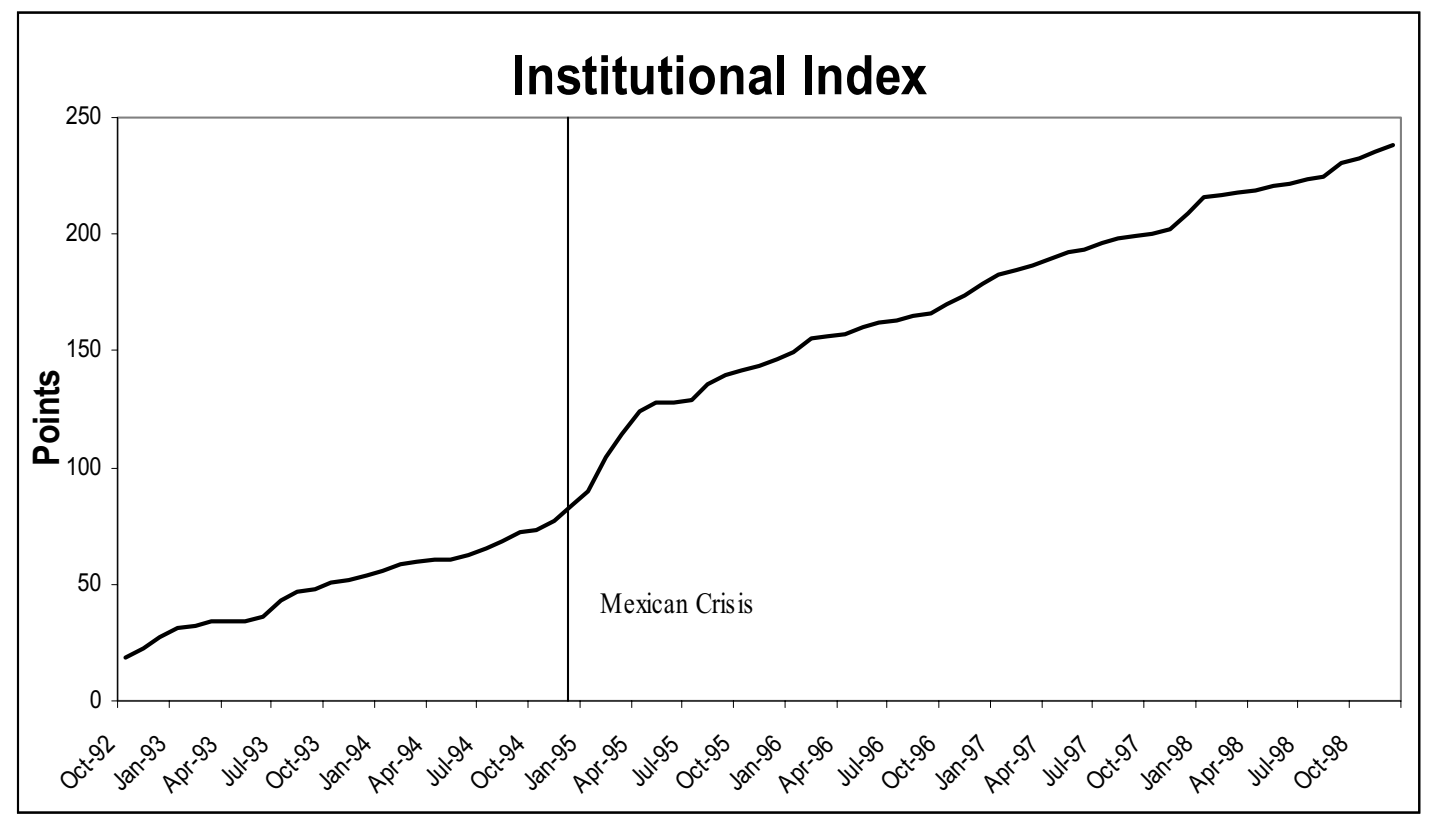

There appears to be a relatively constant trend in our institutional index except for a break in late 1994, coincident with the Tequila crisis. As discussed earlier we want to test the 
causes of institutional change and the impact that institutional change had on the banking sector. To do so we constructed series on the following variables: Dollar Deposits (Dodep), Peso Deposits (Pedep), Total Deposits (Dep), Credit to Private Sector (Finpri), Loans to Provincial Governments (LPG), Credit to Public Sector (FPS), Total Credit (Fin), Monetary Base (MB). We will test causation using Granger causality tests but before doing so we need to test for the presence of a unit root ${ }^{15}$. For our series on institutional change we have the following model:

$I N S T_{t}=\mu+\theta D U_{t}+\delta D\left(T_{B}\right)_{t}+\gamma D T_{t}+\alpha I N S T_{t-1}+\sum_{i=1}^{4} c_{i} \Delta I N S T_{t-i}+e_{i}$

where $\theta$ captures the effect of the change in the level and $\gamma$ the movement in the slope. Table 4 shows the values for these parameters.

Table 4 - Parameter Estimates of Institutional Change

\begin{tabular}{|l|l|l|l|}
\hline Parameter & Estimation & Standard Error & T-statistic (H0: a=0) \\
\hline$\theta$ & 0.202 & 0.0406 & 4.963 \\
\hline$\delta$ & -0.004 & 0.0011 & -3.363 \\
\hline$\gamma$ & 0.0066 & 0.0017 & 3.851 \\
\hline$\alpha$ & 0.7900 & 0.03747 & 21.085 \\
\hline$\mu$ & 0.7667 & 0.1264 & 6.064 \\
\hline
\end{tabular}

The estimate of $\theta$ indicates that there was a break in our series at the time of the Tequila crisis and this was followed by decrease in the rate of change. This is consistent with our narrative of revolution (reform prompted by crisis) and subsequent evolution (a slowdown in the rate of change following the crisis but institutional deepening). This is in contrast to the behavior of the other series of banking indicators, which display a break but no change in the subsequent growth following the break.

We are now in a position to perform Granger causality tests. ${ }^{16}$ In Table 6 , we present the results from our Granger causality tests. Based on these results we reach the following conclusions:

${ }^{14}$ Our results are invariant to the alternative weighting scheme of assigning a 1 to minor and major changes.

${ }^{15}$ See Appendix B for Unit Root test for the mentioned variables.

${ }^{16}$ With the two series $\mathrm{X}$ and $\mathrm{Y}$ we run the following regressions:

$y_{t}=\mu+\sum_{i=1}^{k} \alpha_{i} y_{t-i}+\sum_{i=1}^{k} \beta_{i} x_{t-i}+e_{t}$

The null hypothesis H0: " $\mathrm{x}$ does not cause $\mathrm{y}$ " is tested as $\mathrm{H} 0$ : $\beta_{\mathrm{i}}=0$ for $\mathrm{i}=1, \ldots, \mathrm{k}$; and

$x_{t}=\mu+\sum_{i=1}^{k} \alpha_{i} y_{t-i}+\sum_{i=1}^{k} \beta_{i} x_{t-i}+e_{t}$

The null hypothesis H0: " $\mathrm{y}$ does not cause $\mathrm{x}$ " is tested as H0: $\alpha_{\mathrm{i}}=0$ for $\mathrm{i}=1, \ldots, \mathrm{k}$. 
1) The causes of institutional change are consistent with our narrative on the role of crises. The two series causing institutional change are Peso deposits and the monetary base. The first action taken by Argentines following the Tequila crisis was to convert pesos to dollars in order to hedge the risk from devaluation. As people withdrew pesos, the monetary base contracted. Both declines are signals to politicians and the Central Bank to "do something." As a result, the executive office, the legislature and the Central Bank initiated reforms.

Table 5 - Granger Causality Tests

\begin{tabular}{|c|c|c|}
\hline \multicolumn{3}{|c|}{ H0: "X does not cause $Y$ " } \\
\hline INST $\longrightarrow$ DEPDOL & Reject H0 & (1) INST Granger causes \\
\hline $\mathrm{DEPDOL} \longrightarrow \mathrm{INST}$ & $\begin{array}{l}\text { Reject } \mathrm{H} 0 \text { for } \mathrm{k}=4 \\
\text { Otherwise, Cannot Reject } \mathrm{H} 0\end{array}$ & DEPDOL \\
\hline DEPES & Cannot Reject $\mathrm{H} 0$ & (2) DEPES Granger causes \\
\hline DEPES $\longrightarrow$ INST & $\begin{array}{l}\text { Accept } \mathrm{H} 0 \text { for } \mathrm{k}=1 \\
\text { Otherwise, Reject } \mathrm{H} 0\end{array}$ & INST \\
\hline CRED & Reject H0 & (3) INST Granger causes \\
\hline CRED $\longrightarrow$ & $\begin{array}{l}\text { Reject } \mathrm{H} 0 \text { for } \mathrm{k}=1 \\
\text { Otherwise Cannot Reject } \mathrm{H} 0 \text {. }\end{array}$ & CRED. \\
\hline INST & Cannot Reject H0 & (4) BM Granger causes INST \\
\hline$\longrightarrow \quad$ INST & $\begin{array}{l}\text { Cannot Reject } \mathrm{H} 0 \text { for } \mathrm{k}=6 \text {, } \\
10,11 \text { and } 12 \\
\text { Otherwise, Reject } \mathrm{H} 0\end{array}$ & \\
\hline CRED $\longrightarrow$ & Cannot Reject H0 & (5) DEP Granger Causes \\
\hline$\longrightarrow$ CRED & Reject H0 & CRED \\
\hline LPG $\longrightarrow$ & Cannot Reject H0 & (6) CREDPROV does not \\
\hline $\mathrm{INST} \longrightarrow$ & Cannot Reject H0 & $\begin{array}{l}\text { Granger cause INST. } \\
\text { INST does not Granger cause } \\
\text { CREDPROV }\end{array}$ \\
\hline LPG $\longrightarrow$ & Cannot Reject H0 & (7) DEP Granger causes \\
\hline $\mathrm{DEP} \longrightarrow$ & $\begin{array}{l}\text { Cannot Reject } \mathrm{H} 0 \text { for } \mathrm{k}=1,6 \text {, } \\
10,11 \text { and } 12 \\
\text { Otherwise, Reject } \mathrm{H} 0 \text {. }\end{array}$ & CREDPROV \\
\hline
\end{tabular}

Note: See Appendix B for the complete results of the Granger Causality Tests.

2) Institutional change Granger causes dollar deposits. Reforms in the financial and banking system caused dollar deposits to grow. Between January 1991 and November 1998 dollar deposits grew by $1150 \%$.

3) Both institutional change and total deposits cause an expansion in credit. This is no surprise. No doubt most of the causation is coming through the growth of deposits but the growth 
of deposits in turn results from a belief that the regulatory system reduces the likelihood of bank runs.

4) Institutional change does not cause loans to Provincial governments to increase and neither do loans to Provincial governments prompt institutional change. This is consistent with our historical narrative that stressed the importance of the October 1992 reform of the Central Bank. From this date on (our sample period) there should be no link between institutional change and loans to Provincial banks.

5) Deposits Granger cause loans to Provincial governments. Again, as stressed in our narrative, the huge inflow in deposits following the convertibility plan allowed Provincial banks to continue to lend to Provincial governments, despite the questionable soundness of the loans.

\section{Conclusion}

In this paper we provide an analytical narrative of the political and economic causes and consequences of institutional changes in the Argentine banking system. We devote most of our attention to the privatization of the provincial banks. Our story differs from the prevailing wisdom in its stress on the key roles played by convertibility and an independent Central Bank rather than the Fondo Fiduciario. Though there was more than a two year unanticipated lag between the law establishing an independent Central Bank and the wave of privatizations in 1995, this lag was a result of the enormous inflow of deposits into the system prompted by the successful reception of the convertibility plan. The deposit inflow allowed the provincial banks to remain afloat despite their continued loans to the public sector. Once a crisis hit, causing a deposit outflow, many of the provincial banks were doomed. The Fondo Fiduciario, which some authors credit for the privatizations, no doubt greased the wheels for privatization and perhaps saved the political lives of some politicians, but we do not see the Fondo Fiduciario as critical.

Along with the narrative we provide econometric results indicating that the fall in peso deposits and the contraction in the monetary base in the last quarter of 1994 caused the legislature, the executive office and the Central Bank to initiate reforms to maintain the convertibility plan. Once the reforms were in place they caused deposits and credit to grow. This set in motion a virtuous cycle with continued evolutionary institutional deepening such that the Asian and Russian crises had little impact on the banking system. 


\section{Appendix A: Main Changes on the Regulation of the Banking System.}

The following enumeration contains only the major changes that occurred during the Convertibility Plan. We used these along with more minor changes to construct the Institutional Index. ${ }^{17}$ (The complete list of norms and changes is too large to list here).

1. April 1991: Convertibility Law was enforced.

2. October 1992: Law of the Independence of the Central Bank passed Congress. (Law 24,144). This law specified the functions and obligations of the Central Bank.

3. July 1993: Central Bank set the reserve requirement at $43 \%$.

4. July 1994: New system for determining the assets of financial institutions. This system helped to provide better information on the quality of the investment portfolios of banks.

5. January 1995: Communication A2298 of the Central Bank provided that all the deposits of financial institutions in the Central Bank were denominated in U.S. dollars.

6. February 1995: The Central Bank reduced the reserve requirement from $43 \%$ to $30 \%$.

7. February 1995: By Decree 540/95 the government created the Fondo de Garantía de los Depósitos (Deposits Insurance Fund). This fund insured term deposits of less than 90 days up to US $\$ 10,000$ and insured deposits up to US\$20,000 for terms greater than 90 days.

8. February 1995: Creation of the Fondo Fiduciario para el Desarrollo Provincial (Decree 286/95) (Provincial Development Fiduciary Fund). Created with the aim of helping provincial governments privatize their banks.

9. April 1995: Creation of a Fund to capitalize private banks (Decree 445/95). This fund helped private banks in trouble merge or recapitalize after the Tequila Crisis.

10. April 1995: Changes in the law of the Central Bank that gave a more active role to the Central Bank in the liquidation process of banks.

11. August 1995: The definition of reserves was changed such that banks had to hold a greater proportion of their reserves in more liquid assets.

12. January 1997: Programa de Pases (Passes Program): This program gave the Central Bank the capacity to increase the liquidity in the financial system.

13. February 1997: Duration of the Fiduciary Fund for provinces was extended. Congress gave to the Executive the power to extend the duration of the fund by 15 years (Law 24,623). By Decree 104/97 the president extended the fund to 3 years.

\footnotetext{
${ }^{17}$ For a complete list of changes please contact one of the authors.
} 
14. March 1997: Central Bank communication A2521 established new criteria for the qualification of banks.

15. June 1997: The Central Bank allowed international bonds to qualify as reserves.

\section{Appendix B: Unit Root Tests}

The standard procedures for testing for unit roots are the Dickey-Fuller and Augmented DickeyFuller tests. But, because of a likely break in our time series (the Tequila crisis), we use the Perron (1989) method. By using a known break, the power of the tests increases. ${ }^{18}$ For our series on institutional change we test for changes in its intercept (i.e., a break in the series) and changes in its slope (trend). The model is:

$$
y_{t}=\mu+\theta D U_{t}+\beta t+\gamma D T_{t}+\delta D\left(T_{B}\right)_{t}+\alpha y_{t-1}+\sum_{i=1}^{k} c_{i} \Delta y_{t-i}+e_{t}
$$

where: DU captures the change in the intercept and DT captures the change in the slope; and $\mathrm{D}\left(\mathrm{T}_{\mathrm{B}}\right)=\mathrm{t}$ for $\mathrm{t}>\mathrm{T}_{\mathrm{B}}$.

Under this model the null hypothesis of a unit root process is: $\alpha=1, \beta=0, \theta=0$ and $\gamma=0$. Under the alternative hypothesis: $\alpha<1, \beta \neq 0, \theta \neq 0$ and $\gamma \neq 0$. For the series on banking indicators we only test for changes in the intercept and the model collapses to:

$$
y_{t}=\mu+\theta D U_{t}+\beta t++\delta D\left(T_{B}\right)_{t}+\alpha y_{t-1}+\sum_{i=1}^{k} c_{i} \Delta y_{t-i}+e_{t}
$$

The critical values for the distribution of the parameter $\alpha$ is tabulated according to the measure $\lambda$, where $\lambda=\mathrm{TB} / \mathrm{T}$. The tests for unit root are similar to those of Dickey Fuller but with different critical values. For tables with critical values for $t_{\alpha}$ and $T(\alpha-1)$ see Perron(1989). In Table B1 we summarize our test results.

\footnotetext{
${ }^{18}$ Perron(1997) also mentions the loss of power that models with unknown breaks have. "There appears to be a clear trade-off between power and the amount of prior information one is willing to incorporate with respect to the choice of the break point."
} 
Table B1-Perron Test Results

\begin{tabular}{|c|c|c|c|c|c|c|c|c|c|c|c|c|}
\hline Variable & Sample & $\mathbf{T}$ & $\mathbf{T}_{\mathbf{B}}$ & $\mathbf{K}$ & Model & $\mathbf{t}_{\boldsymbol{\theta}}$ & $\mathbf{t}_{\gamma}$ & $\mathbf{t}_{\beta}$ & $\alpha$ & $\mathbf{t}_{\alpha}$ & Unit Root Test: Probability & $\lambda$ \\
\hline Dodep & $\begin{array}{c}\text { Jan-91 } \\
\text { Nov-98 }\end{array}$ & 95 & Dec-94 & 11 & A & -3.754 & - & 4.002 & 0.897 & -4.37 & (-4.32) Reject H0: $1 \%$ & 0.52 \\
\hline Pedep & $\begin{array}{c}\text { Jan-91 } \\
\text { Nov-98 }\end{array}$ & 95 & Oct-94 & 1 & $\mathrm{~A}$ & -3.393 & - & 3.668 & 0.873 & -4.34 & (-4.32) Reject H0: 1\% & 0.484 \\
\hline Dep & $\begin{array}{c}\text { Jan-91 } \\
\text { Nov-98 }\end{array}$ & 95 & Oct-94 & 12 & $\mathrm{~A}$ & -3.173 & - & 4.097 & 0.883 & -4.38 & (-4.32) Reject H0: 1\% & 0.484 \\
\hline Finpri & $\begin{array}{l}\text { Jan-91 } \\
\text { Nov-98 }\end{array}$ & 95 & Nov-94 & 1 & $\mathrm{~A}$ & -3.814 & - & 4.052 & 0.947 & -5.24 & (-4.32) Reject H0: $1 \%$ & 0.495 \\
\hline Fin & $\begin{array}{c}\text { Jan-91 } \\
\text { Nov-98 }\end{array}$ & 95 & Jan-95 & 1 & $\mathrm{~A}$ & -3.814 & - & 4.296 & 0.923 & -5.57 & (-4.32) Reject H0: 1\% & 0.516 \\
\hline Inst & $\begin{array}{l}\text { Oct-92 } \\
\text { Nov-98 }\end{array}$ & 67 & Nov-94 & 4 & $\mathrm{C}$ & 4.963 & -3.363 & 3.851 & 0.79 & -5.60 & (-4.32) Reject H0: 1\% & 0.388 \\
\hline $\mathrm{BM}$ & $\begin{array}{l}\text { Jan-91 } \\
\text { Nov-98 }\end{array}$ & 95 & Nov-94 & 11 & $\mathrm{~A}$ & -7.27 & - & 7.114 & 0.524 & -8.13 & (-4.32) Reject H0: $1 \%$ & 0.495 \\
\hline
\end{tabular}

Tables with critical values can be found in Perron(1989).

Our results indicate that we can reject the presence of a unit root for all of our variables except for our series on loans to provincial governments (LPG). Consequently we can detrend these variables in order to obtain a stationary process. 
Appendix C: Results of Granger -Causality tests.

\begin{tabular}{|c|c|c|c|c|c|c|c|c|}
\hline \multirow{2}{*}{$\begin{array}{l}\text { INST } \\
\text { Lags }\end{array}$} & \multicolumn{2}{|c|}{ DEPDOL } & \multicolumn{2}{|c|}{ DEPDOL } & \multicolumn{2}{|l|}{ INST } & \multicolumn{2}{|c|}{ DEPES INST } \\
\hline & $\mathrm{F}$ value & $\begin{array}{l}\text { Probabil } \\
\text { ity }\end{array}$ & F-Value & Probability & F-Value & Probability & F value & Probability \\
\hline 1 & 0.27 & 0.6024 & 2.04 & \begin{tabular}{|l|l|}
0.1576 \\
\end{tabular} & 0.23 & 0.6346 & 0.55 & 0.4621 \\
\hline 2 & 5.91 & 0.0000 & 1.35 & \begin{tabular}{|l|l|}
0.2652 \\
\end{tabular} & 0.18 & 0.8320 & 31.19 & 0.0000 \\
\hline 3 & 8.12 & 0.0000 & 0.87 & \begin{tabular}{|l|l|}
0.4709 \\
\end{tabular} & 0.83 & 0.4809 & 24.15 & 0.0000 \\
\hline 4 & 14.99 & 0.0000 & 0.98 & \begin{tabular}{|l|l|}
0.4260 \\
\end{tabular} & 1.24 & 0.3054 & 17.23 & 0.0000 \\
\hline 5 & 17.46 & 0.0000 & 0.71 & \begin{tabular}{|l|l}
0.6187 \\
\end{tabular} & 0.58 & 0.7120 & 13.51 & 0.0000 \\
\hline 6 & 15.42 & 0.0000 & 0.86 & \begin{tabular}{|l|l|}
0.5334 \\
\end{tabular} & 0.57 & 0.7529 & 11.20 & 0.0000 \\
\hline 7 & 15.96 & 0.0000 & 0.54 & \begin{tabular}{|l|l|}
0.7999 \\
\end{tabular} & 0.63 & 0.7272 & 9.8 & 0.0000 \\
\hline 8 & 13.30 & 0.0000 & 0.36 & \begin{tabular}{|l|l|}
0.9384 \\
\end{tabular} & 0.68 & 0.7054 & 10.13 & 0.0000 \\
\hline 9 & 12.07 & 0.0000 & 0.58 & \begin{tabular}{|l|l|}
0.8034 \\
\end{tabular} & 0.71 & 0.6975 & 8.69 & 0.0000 \\
\hline 10 & 10.18 & 0.0000 & 0.49 & \begin{tabular}{|l|l|}
0.8892 \\
\end{tabular} & 0.89 & 0.5528 & 9.68 & 0.0000 \\
\hline 11 & 8.84 & 0.0000 & 0.43 & \begin{tabular}{|l|l|}
0.9346 \\
\end{tabular} & 1.15 & 0.3480 & 9.12 & 0.0000 \\
\hline \multirow[t]{2}{*}{12} & 9.14 & 0.0000 & 0.53 & \begin{tabular}{|l|l|}
0.8778 \\
\end{tabular} & 1.12 & 0.3770 & 7.96 & 0.0000 \\
\hline & INST & CRED & CRED & INST & INST & BM & BM & INST \\
\hline 1 & 9.36 & 0.0031 & 3.67 & \begin{tabular}{|l|l|}
0.0595 \\
\end{tabular} & 0.65 & 0.4242 & 3.85 & 0.0536 \\
\hline 2 & 9.01 & 0.0003 & 0.64 & \begin{tabular}{|l|l}
0.5293 \\
\end{tabular} & 1.04 & $\begin{array}{l}0.5399 \\
\end{array}$ & 3.11 & 0.0510 \\
\hline 3 & 17.33 & 0.0000 & 0.45 & 0.7165 & 0.58 & 0.6320 & 2.71 & 0.0525 \\
\hline 4 & 21.28 & 0.0000 & 0.56 & \begin{tabular}{|l|l|}
0.6929 \\
\end{tabular} & 0.66 & 0.6202 & 2.26 & 0.073 \\
\hline 5 & 18.76 & 0.0000 & 0.49 & \begin{tabular}{|l|l|}
0.7857 \\
\end{tabular} & 0.44 & 0.8155 & 2.35 & 0.0517 \\
\hline 6 & 17.18 & 0.0000 & 0.40 & \begin{tabular}{|l|l|}
0.8735 \\
\end{tabular} & 0.83 & 0.5509 & 1.78 & 0.1201 \\
\hline 7 & 16.31 & 0.0000 & 0.59 & 0.7623 & 0.89 & 0.5231 & 2.95 & 0.0111 \\
\hline 8 & 14.80 & 0.0000 & 0.43 & \begin{tabular}{|l|l|}
0.8973 \\
\end{tabular} & 0.82 & 0.5918 & 2.36 & 0.031 \\
\hline 9 & 13.12 & 0.0000 & 0.56 & \begin{tabular}{|l|l|}
0.8201 \\
\end{tabular} & 0.70 & 0.8029 & 2.06 & 0.0531 \\
\hline 10 & 11.46 & 0.0000 & 0.46 & \begin{tabular}{|l|l|}
0.9058 \\
\end{tabular} & 0.75 & 0.6775 & 1.98 & 0.060 \\
\hline 11 & 10.90 & 0.0000 & 0.47 & 0.9095 & 0.53 & 0.8745 & 1.72 & 0.1039 \\
\hline \multirow[t]{2}{*}{12} & 21.45 & 0.0000 & 0.44 & 0.9353 & 0.71 & 0.7359 & 1.83 & 0.0783 \\
\hline & \multicolumn{2}{|l|}{ CRED } & \multicolumn{2}{|c|}{ DEP CRED } & \multicolumn{2}{|l|}{ LPG } & \multicolumn{2}{|l|}{ INST } \\
\hline 1 & 0.86 & 0.3560 & 17.72 & \begin{tabular}{|l|l}
0.0000 \\
\end{tabular} & 0.42 & 0.5178 & 3.09 & 0.0847 \\
\hline 2 & 2.34 & 0.1031 & 12.49 & \begin{tabular}{|l|l|}
0.0000 \\
\end{tabular} & 0.48 & 0.6217 & 1.52 & 0.2293 \\
\hline 3 & 1.55 & 0.2111 & 18.69 & \begin{tabular}{|l|l|}
0.0000 \\
\end{tabular} & 0.35 & 0.7889 & 1.52 & 0.2236 \\
\hline 4 & 1.21 & 0.3178 & 33.28 & \begin{tabular}{|l|l|}
0.0000 \\
\end{tabular} & 0.16 & 0.9556 & 1.52 & 0.2139 \\
\hline 5 & 0.36 & 0.8768 & 30.40 & 0.0000 & 0.41 & 0.8373 & 1.29 & 0.29 \\
\hline 6 & 0.31 & 0.9293 & 30.69 & \begin{tabular}{|l|l|} 
\\
\end{tabular} & 0.32 & 0.9227 & 2.24 & 0.0622 \\
\hline 7 & 0.74 & 0.6375 & 26.77 & \begin{tabular}{|l|l|}
0.0000 \\
\end{tabular} & 0.39 & 0.9012 & 1.73 & 0.1381 \\
\hline 8 & 0.64 & 0.7374 & 25.37 & 0.0000 & 0.28 & 0.9680 & 1.55 & 0.1825 \\
\hline 9 & 0.51 & 0.8574 & 22.59 & \begin{tabular}{|l|l|}
0.0000 \\
\end{tabular} & 0.28 & 0.9752 & 1.21 & 0.3325 \\
\hline 10 & 0.47 & 0.8979 & 31.94 & \begin{tabular}{|l|l|} 
& 0.0000 \\
\end{tabular} & 0.23 & 0.9902 & 1.27 & 0.3031 \\
\hline 11 & 0.43 & 0.9334 & 27.38 & 0.0000 & 0.38 & 0.9503 & 0.95 & 0.5158 \\
\hline 12 & 0.49 & 0.9048 & 23.52 & \begin{tabular}{|l|l|} 
& 0.0000
\end{tabular} & 0.62 & 0.8013 & 0.61 & 0.8095 \\
\hline
\end{tabular}




\begin{tabular}{|l|l|l|l|l|}
\hline & LPG & DEP & DEP & LPG \\
\hline 1 & 0.93 & 0.3403 & 0.21 & 0.6467 \\
\hline 2 & 0.45 & 0.6417 & 4.97 & 0.0110 \\
\hline 3 & 0.49 & 0.6938 & 3.39 & 0.0261 \\
\hline 4 & 0.35 & 0.8425 & 2.88 & 0.0342 \\
\hline 5 & 0.51 & 0.7692 & 2.71 & 0.0344 \\
\hline 6 & 0.32 & 0.9208 & 2.10 & 0.0784 \\
\hline 7 & 0.28 & 0.9581 & 2.66 & 0.0274 \\
\hline 8 & 0.18 & 0.9926 & 2.70 & 0.0236 \\
\hline 9 & 0.16 & 0.9963 & 2.27 & 0.0492 \\
\hline 10 & 1.94 & 0.0918 & 1.85 & 0.1082 \\
\hline 11 & 1.47 & 0.2188 & 0.78 & 0.6590 \\
\hline 12 & 1.33 & 0.2861 & 0.63 & 0.7867 \\
\hline
\end{tabular}




\section{Bibliography.}

Adelman, Jeremy. "The Politics of Money in Mid-Nineteenth-Century Argentina." In "The New Institutional Economics and Third World Development.” Edited by John Harris, Janet Hunter and Colin M. Lewis. Routledge, London and New York 1995.

Banco Central de la Republica Argentina. “Boletin Estadistico.” Several Issues.

Ben-Daivd, Dan, Lumsdaine, Robin L. and Papell, David H. “Unit Roots, Postwar Slowdowns and long-Run Growth: Evidence from Two Structural Breaks.” NBER. Working paper 6397. February 1998.

Bordo, Michael D. “Currency Crises (and Banking Crises) in Historical Perspective.” Institute För Ekonomisk Historisk Forskning, Research Report \#10, Stockholm 1998

Burdisso, Tamara, D'amato, Laura and Molinari, Andres. "Privatización de bancos en Argentina: ¿El camino hacia una banca más eficiente”? Banco Central de la República Argentina Documento de Trabajo nro. 4, Octubre 1998.

Calomiris, Charles W. and White, Eugene N. “The Origins of Federal Deposit Insurance.” In The Regulated Economy. Edited by Claudia Goldin and Gary D. Libecap. Chicago: University of Chicago Press, 1994, pp. 145-188.

Calvo, Guillermo A. “Varieties of Capital-Market Crises.” In The Debt Burden and its

Consequences for Monetary Policy. Edited by G. Calvo and M. King. International Economic Association by MacMillan, August 1, 1998.

Calvo, Guillermo A. "Why is the Market so Unforgiving? Reflections on the Tequilazo. University of Maryland, September 21, 1996.

Calvo, Guillermo A. and Mendoza, Enrique G. "Rational Behavior and the Globalization of Securities Markets.” March 6, 1998. 
Calvo, Guillermo A. "Understanding the Russian Virus, with respect to Latin America." Deutsche Bank's conference on "Emerging Markets: Can They be Crisis Free?" Washington D.C., October 3, 1998.

Calvo, Guillermo A. "Contagion in Emerging Markets: When Wall Street is a carrier (Technical Supplement to "Understanding the Russian Virus")”. University of Maryland, February 2, 1999.

Caprio Jr., Gerard. “Banking on Crises: Expensive Lessons from Recent Financial Crises.” The World Bank, June 1998.

Caprio Jr., Gerard, Doolwy, Michael, Leipziger, Danny and Walsh, Carl. "The Lender of Last Resort Function Under a Currency Board: The Case of Argentina." World Bank Policy Research Working Paper \#1648, September 1996.

Country Report. “Argentina”. The Economist Intelligence Unit. United Kingdom. Several Issues.

CTA (Consejo de los Trabajadopres Argentinos). Los Nuevos contenidos de las Crisis Provinciales. Las relaciones fiscales y financieras entre la Nacion y las Provincias durante la Convertibilidad. (1996)

Cull, Robert J. “Financial Sector Adjustment Lending, A Mid-Course Analysis.” World Bank Policy Research Working Paper \#1804. August 1997.

Cull, Robert and Clarke, George R.G. "The Political Economy of Privatization: An Empirical Analysis of Bank Privatization in Argentina.” World Bank, September 1997.

Cull, Robert and Clarke, George R.G. "Why Privatize? The Case of Argentina's Public Provincial Banks.” World Bank, $1998 ?$

de Juan, Aristóbulo. "The Roots of Banking Crises: Microeconomic Issues and Supervision and Regulation.” In “Banking Crises in Latin America” Edited by Ricardo Hausmann and Liliana Rojas-Suarez. Inter-American Development Bank, Washington D.C., 1996. 
Demirgüc-Kunt, As11 and Detragiache, Enrica. “The Determinants of Banking Crises: Evidence from Developing and Developed Countries.” IMF Working Paper, September 1997.

Dziobek, Claudia and Pazarbasioglu, Ceyla. "Lessons from Systemic Bank Restructuring: A Survey of 24 Countries.” IMF Working Paper, December 1997.

Dziobek, Claudia. “Market-Based Policy Instruments for systemic Bank Restructuring." IMF Working Paper, August 1998.

The Economist. November $4^{\text {th }}-10^{\text {th }} 2000$.

Fanelli, José M. and Medhora, Rohinton Editors. "Financial Reform in Developing Countries" MacMillan Press LTD, 1998.

Fernandez, Roque "Regulation for a Stable Financial System: Prudential Supervision and Liquidity Management in Argentina." Banco Central de la Republica Argentina

Fernandez, Roque B. and Schumacher, Liliana. "The Argentine Banking Panic After the Tequila Shock: Did Convertibility Help or Hurt?” In "Financial Crisis Management in Regional Blocs. ” Edited by Scheherazade S. Rehman. Kluwer Academic Publishers. Boston/Dordrecht/London, 1998.

Freixas, Xavier and Rochet, Jean-Charles. “Microeconomics of Banking.” The MIT Press.1998.

Ganapolsky, Eduardo J.J. and Schmukler, Sergio L. “Crisis Management in Capital Markets: The Impact of Argentine Policy during the Tequila Effect." World Bank, $1998 ?$

García-Herrero, Alicia. “Banking Crises in Latin America in the 1990's: Lessons from Argentina, Paraguay and Venezuela.” IMF Working Paper, October 1997.

Garcia, Rene and Perron, Pierre. "An Analysis of the Real Interest Rate under Regimen Shifts." The Review of Economics and Statistics, 78 (1995) 111-125.

García, Valeriano F. "Black December, Banking Instability, the Mexican Crisis, and Its Effect on Argentina.” World Bank Latin American and Caribbean Studies, June 1997. 
Gavin, Michael and Hausmann, Ricardo. "The Roots of Banking Crises: The Macroeconomic Context." In "Banking Crises in Latin America” Edited by Ricardo Hausmann and Liliana Rojas-Suarez. Inter-American Development Bank, Washington D.C., 1996.

Ghosh, Atish R., Gulde, Anne-Marie and Wolf, Holger C. "Currency Boards: The Ultimate Fix?” IMF Working Paper, January 1998.

Goldfajn, Ilan and Valdés, Rodrigo O. “Are Currency Crises Predictable?” IMF Working Paper, December 1997.

Goldstein, Morris and Turner, Philip. "Banking Crises in Emerging Economies: Origins and Policy Options.” BIS Economic Papers \#46, October 1996.

Green, William H. “Econometric analysis.” Third Edition. Prentice Hall, 1997.

Hamilton, James D. “Time Series Analysis”. Princeton University Press. 1994.

Harvey, Andrew. "The Econometric Analysis of Time Series.” Second Edition. The MIT Press.1993.

IMF “Report of the Working Group on strengthening Financial Systems.” IMF, October 1998.

Kaminsky, Graciela, Lizondo, Saul and Reinhart, Carmen M. “Leading Indicators of Currency Crises.” World Bank Policy Research Working Paper \#1852, November 1997.

Kane, Edward J. “Capital Movements, Asset Values, and Banking Policy in Globalized Markets." NBER Working Paper Series \#6633, July 1998.

Knight, Malcolm. “Developing Countries and the Globalization of Financial Markets.” IMF Working Paper. July 1998.

Krugman, Paul. “A Model of Balance of Payments Crises.” Journal of Money, Credit and Banking, Volume 11, Issue 3 (Aug., 1979), 311-325.

Langlois, Richard N. "Economics as a Process. Essays in the New Institutional Economics." Cambridge University Press. 1986 
Lumsdaine, Robin L. and Papell, David H. "Multiple Trend Breaks and The Unit Root Hypothesis.” The Review of Economics and Statistics. 79 (1997) 212-218.

Maddala, G.S. and In-Moo Kim. “Unit roots, Cointegration and Structural Change.” Cambridge University Press. 1998

Magnusson, Lars and Ottosson, Jan Editors. "Evolutionary Economics and Path Dependence." Edward Elgar Cheltenham, UK Brookfield, US. 1997

Maxfield, Sylvia. “Effects of International Portfolio Flows on Government Policy Choice.” In “Capital Flows and Financial Crises” edited by Miles Kahler. Cornell University Press, Ithaca, New York, 1998.

Mishkin, Frederic S. "The Mexican Financial Crisis of 1994-95: An Asymmetric Information Analysis." In "Financial Crisis Management in Regional Blocs." Edited by Scheherazade S. Rehman. Kluwer Academic Publishers. Boston/Dordrecht/London, 1998.

North, Douglass C. “Institutions, Institutional Change and Economic Performance.” Cambridge University Press 1990.

Obstfeld, Maurice. "Rational and self-fulfilling Balance of Payments Crises." The American Economic Review, Volume 76, Issue 1 (Mar., 1986), 72-81

Perron, Pierre. "The Great Crash, the Oil Price Shock, and the Unit Root Hypothesis." Econometrica 57, 1361-1401.

Perron, Pierre. "Further evidence on the breaking trend functions in macroeconomic variables." Journal of Econometrics 80 (1997) 355-385.

Reinhart, Carmen M and Reinhart, Vincent Raymond. "Some Lessons for Policy Makers Who deal with the Mixed Blessing of Capital Inflows." In "Capital Flows and Financial Crises” edited by Miles Kahler. Cornell University Press, Ithaca, New York, 1998. 
Reinhart, Carmen and Kaminsky, Graciela. "Financial Crises in Asia and Latin America: Then and Now” January, 1998 American Economic Review: Papers and Proceedings, Vol. 88, May 1998, 444-48.

Ramos, Alberto M. "Capital Structures and Portfolio composition During Banking Crisis: Lessons from Argentina 1995.” IMF Working Paper, August 1998.

Rojas-Suarez, Liliana and Weisbrod, Steven R. “The Do's and Don'ts of Banking Crisis Management." In "Banking Crises in Latin America” Edited by Ricardo Hausmann and Liliana Rojas-Suarez. Inter-American Development Bank, Washington D.C., 1996.

Sachs, Jeffrey D. “Alternative Approaches to Financial Crises in Emerging Markets.” In "Capital Flows and Financial Crises” edited by Miles Kahler. Cornell University Press, Ithaca, New York, 1998.

Sachs, Jeffrey D. “Creditor Panics: Causes and Remedies.” Note prepared for the Cato Conference on Money in the New Millenium, October 22, 1998.

Summers, Lawrence, Ortiz, Guillermo and Mancera, Miguel. “Lessons from Country Experiences: Mexico.” In “Banking Crises in Latin America” Edited by Ricardo Hausmann and Liliana Rojas-Suarez. Inter-American Development Bank, Washington D.C., 1996.

Talvi, Ernesto. “Exchange rate-based stabilization with endogenous fiscal response.” Journal of Development Economics. Vol. 54 (1997) 59-75. 